\title{
INFECTIVIDADE E PROTEÇÃO DE TRÊS ESTIRPES FRACAS DO PAPAYA RINGSPOT VIRUS EM PLANTAS DE MELANCIA
}

\author{
José Segundo Giampan
}

Dissertação apresentada à Escola Superior de Agricultura "Luiz de Queiroz", Universidade de São Paulo, para obtenção do título de Mestre em Agronomia, Área de Concentração: Fitopatologia.

\author{
PIRACICABA \\ Estado de São Paulo - Brasil \\ Dezembro - 2002
}




\title{
INFECTIVIDADE E PROTEÇÃO DE TRÊS ESTIRPES FRACAS DO PAPAYA RINGSPOT VIRUS EM PLANTAS DE MELANCIA
}

\author{
José Segundo Giampan
}

Engenheiro Agrônomo

Orientador: Prof. Dr. JORGE Alberto MARQUes REZEndE

\begin{abstract}
Dissertação apresentada à Escola Superior de Agricultura "Luiz de Queiroz", Universidade de São Paulo, para obtenção do título de Mestre em Agronomia, Área de Concentração: Fitopatologia.
\end{abstract}

\author{
PIRACICABA \\ Estado de São Paulo - Brasil \\ Dezembro - 2002
}




\title{
Dados Internacionais de Catalogação na Publicação (CIP) DIVISÃO DE BIBLIOTECA E DOCUMENTAÇÃO - ESALQ/USP
}

\author{
Giampan, J osé Segundo \\ Infectividade e proteção de três estimpes fracas do Pa paya ringspot virus em \\ plantas de melancia / J osé Segundo Giampan. - - Piracicaba, 2002. \\ $63 \mathrm{p}$. \\ Dissertação (mestrado) - - Esc ola Superior de Agric ultura Luiz de Queiroz, 2002. \\ Bibliografia. \\ 1. Controle biológico (Fitossanidade) 2. Melancia 3. Mosaico (Doença de \\ planta) 4. Potyvinus 5. Virose vegetal I. Título \\ CDD 635.615
}

"Permitida a cópia total ou parcial deste documento, desde que citada a fonte - $\mathrm{O}$ autor" 
Aos meus pais, José Giampan e Maria Fernandes de Jesus pelo apoio, incentivo, confiança e exemplo de dignidade,

\section{DEDICO}

Ao meu irmão, Marcos Antônio; àminha cunhada, Jussara; aos meus sobrinhos, Junior e Mateus, e demais parentes e amigos pelo convívio, carinho, apoio em todos os momentos e pelas alegrias vividas, 
"Pedi e vos será dado. Buscai e achareis. Batei e vos será aberto. Porque todo aquele que pede, recebe. Quem busca, acha.

A quem bate, abrir-se-á."

(Mateus, 7, 7-8)

"No mundo haveis de ter aflições.

Coragem! EU venci o mundo."

(João, 16, 33) 


\section{AGRADECIMENTOS}

À DEUS pela minha vida, saúde e pelos dons recebidos;

Ao professor Dr. Jorge Alberto Marques Rezende pelo profissionalismo, pelos valiosos ensinamentos acadêmicos, conselhos, exigências e cobranças dos deveres cumpridos e incentivos na vida profissional. E, sobretudo, pela amizade e lições de vida;

À Escola Superior de Agricultura "Luiz de Queiroz", especialmente ao Departamento de Entomologia, Fitopatologia e Zoologia Agrícola, pela oportunidade concedida àrealização do curso;

À FAPESP pela concessão da bolsa de mestrado, sem a qual não teria condições de desenvolver este projeto;

Aos professores do Setor de Fitopatologia pelos valiosos ensinamentos e cobranças nas disciplinas, em especial ao professor Hiroshi Kimati que colaborou na diagnose e solução de problemas no experimento em campo;

Aos professores Décio Barbin e Sônia M. S. Piedade do Departamento de Ciências Exatas pela colaboração no planejamento e análise estatística dos dados;

Ao professor Angelo P. Jacomino pela amizade e grandiosos conselhos profissionais e vivenciais; 
Aos funcionários, em especial José Edivaldo Buriola, José Rodolfo Groppo e Pedro C. Arthuso, que colaboraram diretamente nos trabalhos desenvolvidos; e Marise C. Martins que colaborou na diagnose de problemas fitossanitários nos experimentos em campo;

Aos colegas do Laboratório de Virologia Vegetal: Danilo Pedrazzoli, Davi A. Pacheco, Juliana Freitas-Astúa, Louise D. Mota, Luiz C. Rabelo, Marília G. S. Della Vecchia, Paulo E. Oliveira, Quelmo S. Novaes, Ricardo Gioria e Zayame V. Pinto pela amizade, conselhos e colaboração nos trabalhos realizados;

Aos pós-graduandos Alexandre F. S. Mello e Silvio A. M. Alves, e graduando José A. L. F. da Silva pela colaboração direta nos trabalhos e pela amizade;

Aos demais colegas da Pós-graduação da Fitopatologia: Ana Paula A. Mello, Luiz F. C. Ribeiro, Marissônia A. Noronha e Paulo R. Gagliardi;

À Prefeitura do Campus, de modo especial à CAVE, que possibilitou permanecer na Vila da Pós-Graduação durante esses dois anos, e aos colegas da Vila pelo convívio;

À todos aqueles que direta ou indiretamente contribuíram para a realização deste trabalho. 


\section{SUMÁRIO}

Página

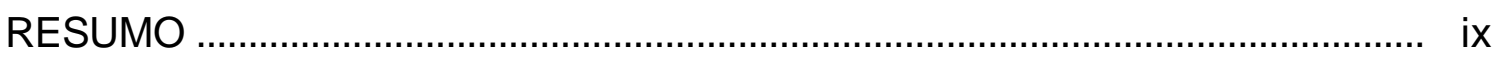

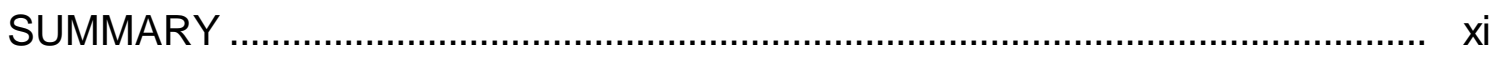

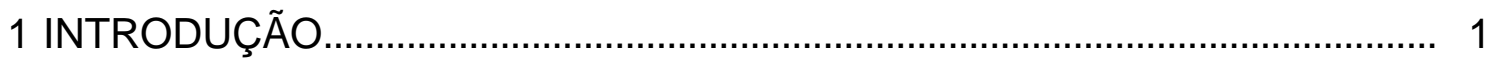

2 REVISÃO DE LITERATURA ....................................................................... 3

2.1 A cultura da melancia................................................................................ 3

2.20 mosaico da melancia ............................................................................. 5

2.3 Premunização no controle de fitoviroses ........................................................ 11

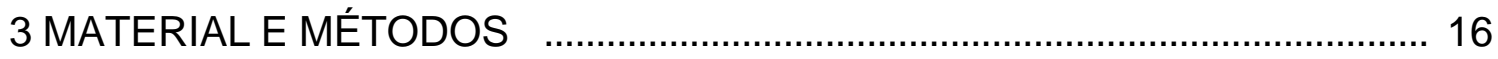

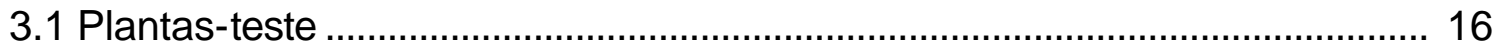

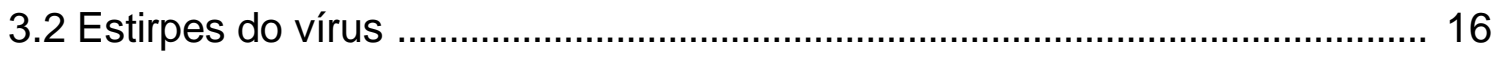

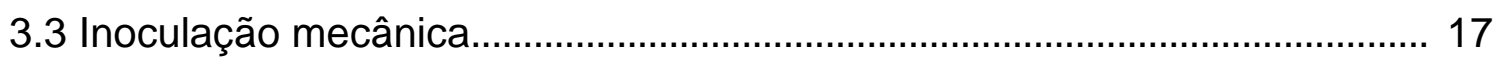

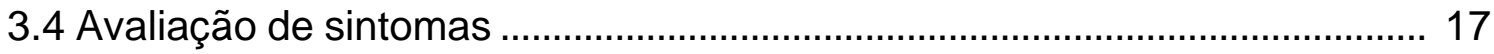

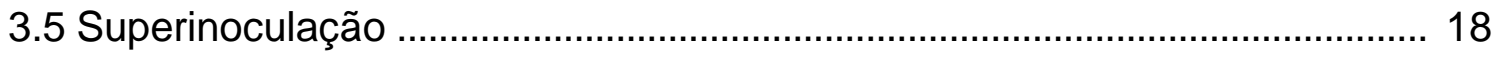

3.6 Teste de recuperação ………............................................................... 18

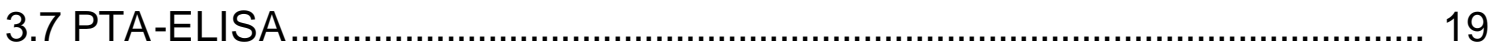

3.8 Seleção de estirpes fracas do PRSV-W a partir de bolhas de folhas de

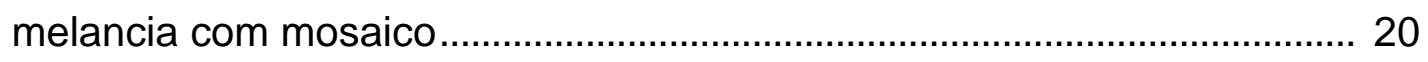

3.9 Teste de infectividade das estirpes fracas do PRSV-W .............................. 21

3.10 Teste de proteção da estirpe fraca obtida de bolhas de folhas de melancia em casa de vegetação .............................................................................. 23

3.11 Teste de proteção das estirpes fracas do PRSV-W em campo................... 23 


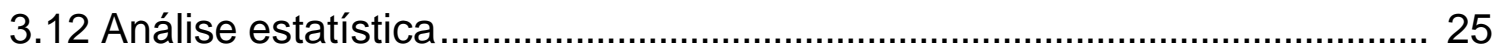

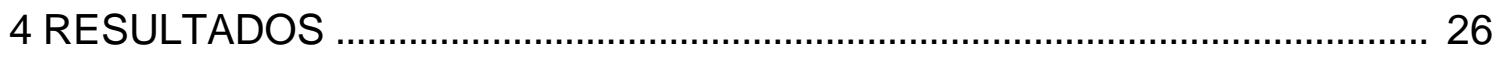

4.1 Estirpe fraca do PRSV-W obtida a partir de bolhas de folhas de melancia

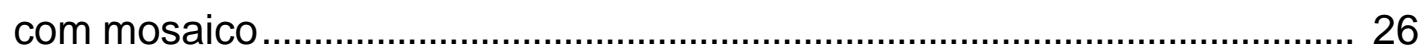

4.2 Infectividade das estirpes fracas do PRSV-W ............................................ 26

4.3 Efeito protetor da estirpe fraca PRSV-W-3 em melancia em casa de

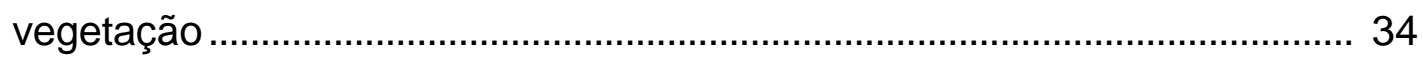

4.4 Efeito protetor das estirpes fracas do PRSV-W em melancia em campo ... 35

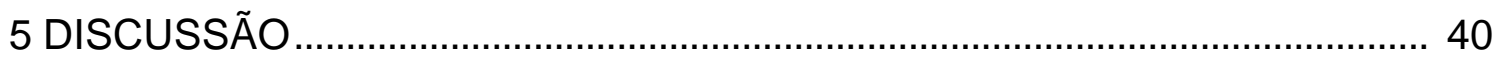

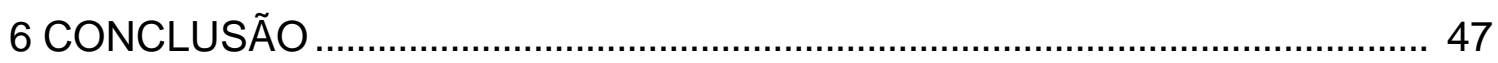

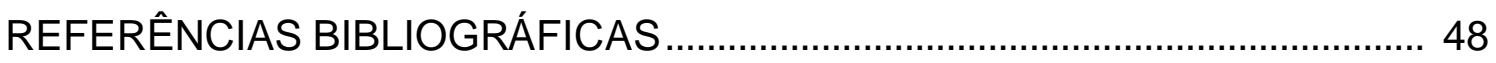




\title{
INFECTIVIDADE E EFEITO PROTETOR DE TRÊS ESTIRPES FRACAS DO PAPAYA RINGSPOT VIRUS EM PLANTAS DE MELANCIA
}

\author{
Autor: JOSÉ SEGUNDO GIAMPAN \\ Orientador: Prof. Dr. JORGE ALBERTO MARQUES REZENDE
}

\section{RESUMO}

Este trabalho teve como objetivo avaliar a infectividade de estirpes fracas do Papaya ringspot virus - type W (PRSV-W) em plantas de melancia (Citrullus lanatus), em função da origem da estirpe fraca, da concentração e da espécie doadora do inóculo e da idade da planta-teste de melancia, inoculada mecanicamente. Também foi avaliado o efeito protetor dessas estirpes em plantas de melancia em casa de vegetação e em campo. A seleção de estirpes fracas do PRSV-W foi feita a partir de bolhas de folhas de melancia infectadas naturalmente em campo. A infectividade da estirpe fraca selecionada foi comparada com a das estirpes fracas PRSV-W-1 e PRSV-W-2, previamente selecionadas de bolhas de folhas de abobrinha de moita (Cucurbita pepo) 'Caserta' com mosaico. Como controle foi utilizada uma estirpe severa do vírus obtida de abobrinha de moita (PRSV-W-C). A avaliação do efeito da concentração e da espécie da planta fonte do inóculo na infectividade de plantas de melancia foi feita com extratos de 4, 8, 12 e 16 discos de folhas de 
abobrinha de moita e de melancia, infectadas separadamente com as estirpes fracas e severa, e diluídos em $2 \mathrm{~mL}$ de tampão fosfato. $O$ efeito da idade da planta-teste de melancia na infectividade das estirpes fracas foi estudado comparando-se plantas inoculadas em quatro estádios de desenvolvimento, a partir do estádio cotiledonar, com inóculos das diferentes estirpes do PRSV-W extraídos de 12 discos foliares/2 $\mathrm{mL}$ de tampão. O efeito protetor da estirpe fraca obtida de bolhas de folhas de melancia com mosaico foi avaliado em plantas premunizadas e desafiadas com a estirpe PRSV-W-C, em casa de vegetação e em campo. Plantas de melancia premunizadas com as estirpes fracas PRSV-W-1 e PRSV-W-2 e plantas não protegidas também foram avaliadas no teste em campo. Foram avaliadas a proteção, com base nos sintomas, a produção e o conteúdo de açúcares (grau brix) dos frutos colhidos das plantas premunizadas e não premunizadas. Uma estirpe fraca do vírus, denominada PRSV-W-3, foi selecionada de bolhas de folhas de melancia com mosaico. Em todos os testes de infectividade em plantas de melancia, independente da concentração e da planta fonte do inóculo e do estádio de desenvolvimento da planta-teste inoculada, a estirpe fraca PRSV-W-3 apresentou taxas de infectividade semelhantes as das estirpes PRSV-W-1 e PRSV-W-2, chegando a $100 \%$ em alguns casos. A infectividade da estirpe severa PRSV-W-C foi de $100 \%$ em todos os testes. Aparentemente, a infectividade das três estirpes fracas foi mais diretamente afetada pela intensidade de fricção das folhas no momento da inoculação mecânica do que pelas variáveis estudadas. A estirpe fraca PRSV-W-3 protegeu as plantas de melancia contra a infecção e/ou manifestação da estirpe PRSV-W-C em casa de vegetação. Em campo, todas as plantas de melancia premunizadas com as três estirpes fracas também ficaram protegidas contra a estirpe severa utilizada no desafio. A produção das plantas premunizadas não diferiu estatisticamente entre si, nem mesmo daquelas inicialmente sadias infectadas em campo. $O$ conteúdo de açúcares e a aparência da polpa dos frutos também foram semelhantes em todos os tratamentos. 


\title{
INFECTIVITY AND PROTECTIVE EFFECT OF THREE MILD STRAINS OF PAPAYA RINGSPOT VIRUS IN WATERMELON PLANTS
}

\author{
Author: JOSÉ SEGUNDO GIAMPAN \\ Adviser: Prof. Dr. JORGE ALBERTO MARQUES REZENDE
}

\section{SUMMARY}

The purpose of this work was to evaluate the infectivity of three mild strains of Papaya ringspot virus - type W (PRSV-W) on watermelon (Citrullus lanatus). The effect of the origin of the mild strain, the concentration of the inoculum, the species of the source of the inoculum and the age of the test-plant on the infectivity of mechanically inoculated watermelon were also evaluated. The protective effect of these mild strains on preimmunized watermelon plants was evaluated under greenhouse and field conditions. Mild strains were selected from blisters formed on mosaic leaves of naturally infected watermelon plants. The infectivity of the selected mild strain was compared with that of mild strains PRSV-W-1 and PRSV-W-2, which were previously obtained from blisters formed on mosaic leaves of zucchini squash (Cucurbita pepo cv. Caserta). A severe strain isolated from zucchini squash (PRSV-W-C) was used as control. The effect of the concentration and the species source of inoculum of the mild strains on the infectivity of watermelon plants was studied with inoculum extracted from 4, 8, 12 and 16 leaf discs of zucchini squash and watermelon 
plants, separately infected with the mild and severe strains, diluted in $2 \mathrm{~mL}$ of phosphate buffer. Four stages of development of watermelon plants, starting at the cotyledonal stage, were tested for the infectivity with the mild strains. Inocula were prepared with extracts of 12 leaf discs diluted in $2 \mathrm{~mL}$ of phosphate buffer. The protective effect of the mild strain selected from blisters on mosaic leaves of watermelon plants was evaluated on preimmunized plants challenge inoculated with severe strain PRSV-W-C, under greenhouse and field conditions. Watermelon plants preimmunized with mild strains PRSV-W-1 and PRSV-W-2 and unprotected plants were also included in the field trial. Protection was evaluated based on plant simptons, yield and sugar content in the fruits. One mild strain, named PRSV-W-3, was obtained from blisters on mosaic leaves of watermelon plants. The rate of infection of watermelon plants with mild strain PRSV-W-3 was similar to that with mild strains PRSV-W-1 and PRSV-W-2 in all infectivity tests, independently of the concentration of the inoculum, species source of the inoculum and stage of development of the inoculated test-plant, reaching $100 \%$ in some cases. Rate of infectivity with severe strain PRSV-W-C was always $100 \%$. Apparently, the infectivity of the mild strains on watermelon was more directly related with the intensity of the abrasion produced by mechanical inoculation than with the above studied variables. The selected mild strain PRSV-W-3 protected watermelon plants against superinfection with the severe strain in the greenhouse tests. Protection was also effective under field conditions. Yield of plants preimmunized with all three mild strains and unprotected plants were statistically similar. The sugar content and the quality of the pulp of the fruits were similar for all treatments. 


\section{INTRODUÇÃO}

A melancia (Citrullus lanatus (Thunb.) Matsum \& Nakai) é descrita como a mais popular das cucurbitáceas em todo o mundo (Robinson \& DeckerWalters, 1997). No Brasil, essa olerícola é considerada uma das mais produzidas e comercializadas (Castellane \& Cortez, 1995 e Food and Agriculture Organization-FAO, 2002). No Estado de São Paulo, é a sexta em quantidade produzida, participando com cerca de 5,9\% da produção total de olerícolas (Instituto de Economia Agrícola - IEA, dados fornecidos por Camargo Filho ${ }^{1}$ ). É ainda uma das principais olerícolas em exportação, tendo como principal importador a Argentina (IEA, 1998).

A ocorrência de viroses tem se constituído num problema de grande relevância no cultivo da melancia, assim como da maioria das cucurbitáceas. Dentre as viroses, a causada pelo "Papaya ringspot virus - type Watermelon" (PRSV-W) é considerada a de maior importância, o que se deve à predominância do vírus em áreas importantes de produção de cucurbitáceas no Estado de São Paulo (Yuki et al., 2000), em regiões do Submédio São Francisco (Ávila et al., 1984 e Lima et al., 1997), nos Estados do Ceará (Ramos et al., 2002) e do Mato Grosso (Stangarlin et al., 2000 e Stangarlin et al., 2001), além de estar presente em outros estados brasileiros. Além disso, é considerada uma das viroses mais destrutivas das cucurbitáceas (Rezende \& Pacheco, 1998).

O controle do mosaico em melancia é muito difícil devido ao baixo nível de resistência ou tolerância da maioria dos cultivares disponíveis, à baixa

\footnotetext{
${ }^{1}$ CAMARGO FILHO, W.P. de. (Instituto de Economia Agrícola-IEA). Comunicação pessoal, 2000.
} 
eficiência do controle químico dos afídeos vetores e à dificuldade da utilização prática de métodos culturais que minimizem a disseminação do vírus nos plantios (Chalfant et al., 1977; Costa \& Costa, 1971; Moore et al., 1965; Wyman et al., 1979 e Yuki, 1990). O uso da premunização com estirpes fracas protetoras tem demonstrado grande eficiência no controle dessa virose em abobrinha de moita (Cucurbita pepo L.) cv. Caserta (Rezende, 1996 e Rezende \& Pacheco, 1998); abóbora rasteira (C. moschata (Duch. ex Lam) Duch ex Poir) cv. Menina Brasileira (Rezende et al., 1999); e em abóbora híbrida (C. maxima Duch. ex Lam x C. moschata) 'Tetsukabuto' (Dias \& Rezende, 2000). Entretanto, a premunização de melancia com as estirpes fracas selecionadas a partir de bolhas de folhas de abobrinha de moita com mosaico (Rezende et al., 1994) não mostraram efeitos tão satisfatórios como nas espécies anteriormente mencionadas. Dias \& Rezende (2001) notaram, inicialmente, que essas estirpes fracas apresentaram baixa infectividade em plantas de melancia, sendo necessárias duas inoculações para permitir a infecção de aproximadamente $80 \%$ das mudas. Além disso, em três testes em campo, os autores verificaram reduções variando de 10,8 a 50\% na produção das plantas premunizadas em relação às sadias, apesar do eficiente efeito protetor das estirpes fracas contra a manifestação de estirpes severas do vírus. A baixa infectividade das estirpes fracas em melancia, conforme propuseram Dias \& Rezende (2001), pode estar associada à especificidade das estirpes, uma vez que foram obtidas de plantas do gênero Cucurbita.

Diante desses fatos e objetivando viabilizar o uso da premunização para o controle do mosaico em melancia, foi proposto selecionar estirpes fracas a partir de plantas de melancia infectadas naturalmente com o PRSV-W e comparar a sua infectividade com a das estirpes fracas selecionadas em plantas de $C$. pepo. Adicionalmente, testes de proteção em casa de vegetação e em campo foram conduzidos para avaliar comparativamente o efeito protetor dessas estirpes fracas e o seu efeito na produção. 


\section{REVISÃO DE LITERATURA}

\subsection{A cultura da melancia}

A melancia [Citrullus lanatus (sin. C. vulgaris Schrad.)], originária da África Tropical, pertence àfamília Cucurbitaceae, considerada uma das famílias de olerícolas mais importantes e constituída por aproximadamente 118 gêneros e 825 espécies. Essa espécie é relatada como sendo a cucurbitácea mais popular em todo o mundo (Robinson \& Decker-Walters, 1997). A produção mundial, estimada em 2001, foi de aproximadamente 77 milhões de toneladas. A maior produção é encontrada na Ásia, sendo a China o maior produtor mundial, com aproximadamente $69 \%$ da produção; vindo em seguida a Turquia e o Irã. Destacam-se também o Egito, na África, como o quarto maior produtor; e os Estados Unidos, na América, como o quinto produtor mundial (FAO, 2002).

No Brasil, a melancia é considerada a quarta olerícola em volume produzido, sendo superada apenas pelo tomate, batata e cebola (Camargo Filho \& Mazzei, 2002; Castellane \& Cortez, 1995 e FAO, 2002). A produção brasileira de melancia em 1999, foi de 2,19 milhões de toneladas, provenientes de uma área de 80,2 mil ha. Esta produção está distribuída por todos os estados brasileiros, destacando-se as regiões Nordeste e Sul como as de maior produção. Os principais estados produtores de melancia em 1999 foram: Rio Grande do Sul (19,8\%), Bahia (16,6\%), São Paulo (14,1\%), Goiás $(8,0 \%)$, Pernambuco $(5,2 \%)$ e Maranhão $(4,0 \%)$. Em relação à área cultivada, a tendência foi praticamente a mesma: RS (23,1\%), BA (16,4\%), SP $(11,0 \%)$, MA $(8,3 \%)$ e GO (8,2\%) (FNP Consultoria \& Comércio, 2002). 
A importância da produção de melancia vem se refletindo nas exportações, sendo que é a segunda olerícola mais exportada em quantidade e valor, perdendo apenas para o melão (IEA, 1998). Em 1999, foram exportadas 13.146 toneladas, correspondendo a um valor de US\$1,8 milhões. O principal país importador da melancia brasileira é a Argentina, com $71 \%$ do total, seguida pelo Uruguai, Países Baixos e Reino Unido (Secretaria de Comércio Exterior SECEX, dados fornecidos por Vilela ${ }^{2}$ ).

No Estado de São Paulo, a melancia é a sexta olerícola em quantidade e participa com $5,9 \%$ da produção total de olerícolas, sendo precedida pela batata, tomate, cebola, repolho e cenoura. Em área plantada, essa espécie ocupa a sétima posição, com $5,4 \%$ da área total de olerícolas (EA, dados fornecidos por Camargo Filho ${ }^{3}$ ). Em 2000, a produção de melancia em São Paulo foi estimada em 207.000 toneladas, em uma área plantada de 7.770 ha, o que corresponde a um rendimento médio de 26,64t/ha. As principais regiões produtoras de melancia no Estado estão situadas nos pólos de desenvolvimento rural de: Marília (21,0\%), Presidente Prudente $(12,0 \%)$, Ourinhos (9,0\%), Tupã $(8,7 \%)$, Assis $(7,6 \%)$, Sorocaba $(6,8 \%)$ e Itapetininga $(5,0 \%)$ (Camargo Filho \& Mazzei, 2002).

Durante o ano de 2000, foram comercializadas na CEAGESP-SP 82 mil toneladas de melancia, sendo que destas, 80 mil apenas de variedades redondas. O preço médio da melancia redonda, nesse ano, foi de US\$ 0,19 / Kg (FNP Consultoria \& Comércio, 2002). Os meses de outubro, novembro e dezembro são os de maior volume de melancia comercializada na CEAGESP. Os meses de baixa comercialização vão de abril a setembro. Os melhores preços recebidos coincidem com o primeiro semestre, com pico em fevereiro e baixa em novembro (Chabaribery \& Alves, 2001). A principal forma de consumo da melancia é como fruta fresca, sendo que na África, os frutos são cozidos. Os

\footnotetext{
${ }^{2}$ VILELA, N.J. (EMBRAPA. Centro Nacional de Pesquisa de Hortaliças). Comunicação pessoal, 2000.

${ }^{3}$ CAMARGO FILHO, W.P. de. (Instituto de Economia Agrícola-IEA). Comunicação pessoal, 2000.
} 
frutos ainda são utilizados como fontes de sucos ou bebidas fermentadas. As sementes também são consumidas torradas (Robinson \& Decker-Walters, 1997).

\subsection{0 mosaico da melancia}

As cucurbitáceas em geral estão sujeitas a várias doenças causadas por vírus, que podem reduzir substancialmente a sua produtividade. Cerca de 50 vírus já foram relatados em cucurbitáceas, sendo que mais de 30 infectam naturalmente plantas desta família (Lima et al., 1999 e Robinson \& DeckerWalters, 1997). Desses, oito foram encontrados no Brasil até 1995: os vírus do mosaico da abóbora (Squash mosaic virus- SqMV) (Chagas, 1970); do mosaico do pepino (Cucumber mosaic virus- CMV) (Costa et al., 1972); do mosaico do mamoeiro - estirpe melancia (Papaya ringspot virus - type W) (Albuquerque et al.,1972); da clorose letal da abobrinha (Zucchini lethal chlorosis virus) (Kitajima \& Costa, 1972; Pozzer et al.,1994 e Rezende et al., 1995); da necrose da abóbora (provável Necrovirus) (Lin et al., 1983); do mosaico-27 da melancia (Watermelon mosaic virus-2 - WMV-2) (Sá \& Kitajima, 1991); um possível Rhabdovirus (Kitajima et al., 1991) e o vírus do mosaico amarelo da abobrinha (Zucchini yellow mosaic virus - ZYMV) (Vega et al., 1992 e 1995).

Dentre esses, o PRSV-W, originalmente descrito como Watermelon mosaic virus - 1 (WMV-1) (Van Regenmortel, 1971), é considerado um dos vírus mais importantes, devido a sua predominância em diversas regiões produtoras de cucurbitáceas no país e aos significativos prejuízos à produção (Albuquerque et al., 1972; Lima et al., 1980; Lima \& Vieira, 1992; Pavan et al., 1989 e Yuki et al., 1991). Estudos recentes sobre a incidência de cinco vírus em cucurbitáceas em São Paulo confirmaram que o PRSV-W foi 0 mais freqüentemente encontrado, ocorrendo em 297 amostras das 605 testadas (49\%). O ZYMV, o ZLCV, o CMV e o WMV-2 foram detectados em 150 amostras das 605 testadas (24,8\%), em 48 das 612 (7,8\%), em 30 das 497 
(6\%) e em 19 das 423 amostras (4,5\%), respectivamente (Yuki et al., 2000). Analizando a ocorrência dessas viroses em melancia, constatou-se também a predominância do PRSV-W, estando presente em 22 amostras das 32 testadas (68,75\%), seguido pelo ZYMV, 6 em 32 (18,75\%); WMV-2, 1 em 15 (6,67\%); CMV, 1 em 24 (4,17\%); e ZLCV, 1 em 32 (3,12\%).

Em áreas importantes de produção de melancia, o PRSV-W tem provocado grandes prejuízos. Ávila et al. (1984) descreveram esse vírus pela primeira vez na região do Submédio São Francisco, importante região produtora de melão e melancia no Brasil, onde ele foi considerado o único em importância econômica, causando uma progressiva redução na área de plantio destas duas espécies. Lima et al. (1997), em um levantamento de viroses na cultura da melancia em áreas de Projetos de Irrigação no Submédio São Francisco, relataram a predominância do PRSV-W, identificado em 49,1\% das 269 amostras analisadas, seguido pelo WMV-2 (13\%) e CMV (1,9\%). Cruz et al. (1999), após analisarem 80 amostras de melancia e melão, provenientes dessa mesma região, constataram que os vírus mais freqüentes foram o WMV-2 e o PRSV-W, com incidências de 68,7\% e 31,2\%, respectivamente.

O PRSV-W também predomina no Estado do Ceará, como constatado por Lima \& Vieira (1992) durante inspeção em campos de cucurbitáceas em 25 municípios. Após analisarem 118 amostras de cucurbitáceas com sintomas de viroses, detectaram a presença desse vírus em $80 \%$ delas. O CMV e o SqMV foram constatados em $15 \%$ e $5 \%$ das amostras, respectivamente. No Estado do Maranhão, Moura et al. (2001) também constataram a predominância do PRSVW. Em campos de produção de cucurbitáceas, os autores identificaram esse vírus em 64,4\% das 118 amostras analisadas, sendo seguido pelo WMV-2 (15,2\%), CMV (6,8\%), SqMV (3,4\%) e ZYMV (3,4\%). Nas amostras coletadas de campos de melancia, foram identificados apenas o PRSV-W (60\%) e o WMV-2 (26,7\%). Em levantamentos feitos em campos experimentais de meloeiro no município de Paraipaba/CE durante o segundo semestre de 1999 e 
2001, Ramos et al. (2002) relataram que o PRSV-W continuava sendo o vírus predominante no Estado, tendo sido encontrado em 78,5\% das amostras analisadas. Nesse mesmo trabalho, o WMV-2, o ZYMV e o CMV foram detectados em $12 \%, 5,8 \%$ e 5,3\% das amostras, respectivamente; e o SqMV não foi constatado.

$\mathrm{Na}$ região Centro-Oeste, mais precisamente no Estado do Goiás, o PRSV-W foi detectado nos municípios de Inhumas e Anápolis em plantios de abóbora, melancia e pepino (Cupertino et al., 1988). No Estado do Mato Grosso do Sul, Stangarlin et al. (2000) analisaram 103 amostras de plantas sintomáticas de abóbora, abobrinha de moita, melancia, melão e pepino, coletadas nas regiões de Dourados, Eldorado e Mundo Novo, tendo comprovado a predominância do PRSV-W (57\%), seguido pelo ZYMV (31\%) e ZLCV (5\%). Em um ensaio de avaliação de 31 genótipos de abóboras e abobrinhas de moita, realizado em Dourados/MS, Stangarlin et al. (2001) também observaram a predominância do PRSV-W (81\%), seguido do ZLCV (42\%), ZYMV (29\%), CMV (6\%) e SqMV (3\%).

O PRSV-W é uma espécie do gênero Potyvirus, da família Potyviridae. É transmitido por diversas espécies de afídeos de modo não persistente. São descritas mais de 20 espécies vetores do PRSV-W sendo que as principais são Aphis craccivora Koch, A. gossypii Glover, A. spiraecola Patch e Myzus persicae Sulzer (Adlerz, 1974 e Yuki, 1990), além de Aulacorthum solani Kaltenbach, Lipaphis erysimi Kltb., Macrosiphum euphorbiae Thomas e Toxoptera citricidus Kirk (Giampan \& Rezende, 2001 e Zitter et al., 1996). Entre essas espécies, Myzus persicae é considerada uma das mais eficientes (Adlerz, 1974; Giampan \& Rezende, 2001 e Yuki, 1990) e uma das mais coletadas em armadilhas em campo (Costa, 1970). Entretanto, dessas espécies, apenas $A$. gossypii é considerada praga das cucurbitáceas, colonizando plantas desta família (Gallo et al., 1988). 
O PRSV-W parece infectar sistemicamente apenas plantas da família Cucurbitaceae (Giampan \& Rezende, 2001 e Gourgopal Roy et al., 1999). Já Purcifull et al. (1984) relataram que o PRSV-W pode infectar também plantas da família Chenopodiaceae, sendo que apenas alguns isolados do vírus foram descritos causando infecção localizada em Chenopodium amaranticolor Coste \& Reyn e C. quinoa Willd. As estirpes brasileiras estudadas até o momento não causam lesões locais nessas duas espécies (Oliveira et al., 2000; J.A.M. Rezende, dados não publicados). Há, entretanto, relatos de outras espécies vegetais, fora da família Cucurbitaceae, como prováveis hospedeiras sistêmicas desse vírus, tais como Cleome viscosa L., C. spinosa Jacq., Malvaviscus arboreus Cav., Sida rhombifolia L.; Sphaeralcea angustifólia (Cav.) G. Don e Tridax procumbens L. (Jimenez Diaz, 1996 e Sánchez et al., 1998). Esses relatos de hospedeiras sistêmicas do PRSV-W devem ser interpretados com cautela, pois foram baseados apenas em testes serológicos, sem avaliar a infecção das espécies com o vírus. Reações serológicas cruzadas entre espécies da família Potyviridae são conhecidas (Gourgopal Roy et al., 1999 e Shukla et al., 1992). Além disso, Giampan \& Rezende (2001) estudaram a reação de 53 espécies vegetais a duas estirpes fracas e uma severa do PRSV$\mathrm{W}$, sendo que entre as espécies testadas estavam C. amaranticolor, C. quinoa, M. arboreus, S. rhombifolia e T. procumbens. As duas primeiras espécies não apresentaram lesões locais quando inoculadas mecanicamente com as três estirpes do PRSV-W. As três últimas espécies vegetais, não pertencentes à família Cucurbitaceae, não foram infectadas sistemicamente pelas mesmas estirpes do vírus.

O PRSV-W é considerado um dos patógenos mais destrutivos em cucurbitáceas no Brasil (Rezende \& Pacheco, 1998). As plantas infectadas apresentam significativa redução na produção e na qualidade dos frutos (Pavan, 1985; Rezende, 1996 e Yuki, 1990). Os danos na produção são variáveis, podendo atingir $100 \%$ quando a espécie cultivada é bastante sensível 
e a infecção ocorre no início do desenvolvimento (Rezende, 1996). Plantas de melancia infectadas com o PRSV-W geralmente exibem mosaico e deformidades foliares, redução no limbo foliar e no desenvolvimento vegetativo e prejuízos na produção, devido à redução no número e no tamanho dos frutos. Em áreas de Projetos de Irrigação do Submédio São Francisco, o PRSV-W foi responsável por danos de até $100 \%$ em algumas áreas, principalmente quando a infecção ocorreu na fase inicial de desenvolvimento das plantas (Lima et al., 1999).

As medidas recomendadas para 0 controle do mosaico em cucurbitáceas, inclusive em cultivos de melancia, incluem o uso de variedades resistentes ou tolerantes; a destruição de plantios velhos e abandonados antes do início da nova cultura; a eliminação de hospedeiras dos vetores, contidas na vegetação espontânea, que ocorrem próximas da área de plantio; programas de controle de afídeos com pulverizações de inseticidas e óleos minerais e uso de substâncias reflectivas (Lovisolo, 1980 e Yuki, 1990). Os métodos químicos e culturais são considerados pouco eficientes para eliminar ou minimizar a ação dos vetores, já que o PRSV-W é transmitido de forma não persistente por várias espécies de afídeos (Perring et al., 1999 e Rezende \& Pacheco, 1998).

A resistência genética é considerada a melhor e mais eficiente forma de controle de viroses em geral. Estudos de avaliação de germoplasma de melancia a viroses têm exibido resultados promissores (Lima et al., 1999). Azevedo et al. (1998) descreveram o acesso PI 595201 como tendo um bom nível de tolerância ao mosaico causado pelo PRSV-W. Azevedo (2001) demonstrou que há, provavelmente, 2 a 3 locos envolvidos no controle da tolerância desse acesso ao mosaico causado pelo PRSV-W, com ação predominantemente aditiva, evidenciando tratar-se de herança oligo ou poligênica. Hojo et al. (1991), avaliando 20 cultivares e híbridos de melancia, identificaram apenas um acesso selvagem, de fruto amargo, denominado BT 8501, originário da África, com tolerância ao mosaico causado pelo PRSV-W. 
Apesar desse acesso ter apresentado ausência total de sintomas nas folhas e frutos, a multiplicação viral foi detectada quando extratos destas folhas foram inoculados em abobrinha de moita 'Caserta'. Segundo Sittolin (1998), esse acesso é ainda tolerante aos mosaicos causados pelo ZYMV e WMV-2. A tolerância desse acesso aos mosaicos causados pelo PRSV-W, ZYMV e WMV2 parece estar associada a dois pares de genes recessivos. Strange et al. (2002) realizaram uma seleção a partir de 1275 acessos em coleções de germoplasma para resistência ao PRSV-W, tendo como controle suscetível o cultivar Charleston Gray. Os acessos que apresentaram melhor resistência (tolerância) foram PI 244017, PI 244018, PI 482342, PI 234287 e PI 482303. Além desses, alguns acessos que possuíam comprovada resistência a outros vírus apresentaram resistência (tolerância) ao PRSV-W. Nesse caso, encontraram-se os acessos PI 482299, PI 482261, PI 595203 e PI 255137 resistentes ao ZYMV; e PI 244018 e PI 244019 resistentes ao WMV-2. Apesar desses estudos, até o momento, aparentemente todos os cultivares disponíveis no mercado brasileiro são suscetíveis ao PRSV-W e com pouca tolerância ao mosaico.

Plantas transgênicas resistentes a vírus constituem-se em outra alternativa de controle de fitoviroses que tem apresentado resultados promissores em cucurbitáceas. Entretanto, até o momento, apenas um cultivar de $C$. pepo transgênico resistente ao WMV-2 e ao ZYMV, denominada 'Freedom II', produzida pela companhia de sementes Asgrow, foi liberada comercialmente nos Estados Unidos (APSNET, 2002). Diversas linhagens transgênicas com resistência tripla CZW-3), dupla (ZW-20) ou simples (C-14, Z-33 e W-164) ao CMV, ZYMV e WMV-2 também foram desenvolvidas (Fuchs et al., 1998 e Robinson \& Decker-Walters, 1997), porém não há relatos de utilização comercial. Também não há relatos de cucurbitáceas transgênicas resistentes ao PRSV-W. 


\subsection{Premunização no controle de fitoviroses}

A premunização é um método de controle de fitoviroses onde plantas previamente infectadas por uma estirpe fraca ficam protegidas contra a infecção e/ou manifestação de estirpes mais severas do complexo (Dodds, 1982). No Brasil, a premunização tem sido usada há mais de 30 anos, com grande êxito, no controle da tristeza dos citros (Citrus tristeza virus-CTV) (Müller \& Carvalho, 2001 e Müller \& Costa, 1968 e 1977). Outros exemplos de sucesso obtidos com essa tecnologia merecem ser citados, tais como os controles do "swollen shoot" do cacaueiro (Cocoa swollen shoot virus-CSSV) no continente africano (Posnette \& Todd, 1955); do endurecimento do frutos do maracujazeiro (Passion fruit woodiness virus-PWV) na Austrália (Simmonds, 1959), onde é utilizada comercialmente em combinação com híbridos tolerantes (Pares et al., 1985 e Peasley \& Fitzell, 1981); do mosaico comum da soja (Soybean mosaic virus-SMV), onde essa tecnologia é utilizada para a produção de sementes com baixa taxa de incidência do vírus no Japão (Kosaka \& Fukunishi, 1993 e 1994); do mosaico do pepino (Cucumber mosaic virus-CMV), com a adição de RNA satélites, em pimentão na China (Tien et al., 1987), em pimentão, melão e tomateiro nos Estados Unidos (Montasser et al., 1991 e 1998) e em tomateiro na Itália (Gallitelli et al., 1991). Há notícias da aplicação comercial dessa tecnologia para o controle do mosaico causado pelo CMV na cultura do pimentão no Japão $\left(\right.$ Kaper $\left.^{4}\right)$.

$\mathrm{Na}$ década de 70, a premunização foi estabelecida e utilizada comercialmente também para o controle do mosaico do tomateiro (Tomato mosaic virus-ToMV) em cultivos protegidos na Holanda e na Inglaterra (Channon et al., 1978; Fletcher, 1978 e Rast, 1972 e 1975); entretanto, devido à falta de proteção contra determinadas estirpes comuns do vírus e ao desenvolvimento de variedades de tomateiro resistentes ao ToMV, a

\footnotetext{
${ }^{4}$ Kaper, J.M. Comunicação pessoal ao orientador desse trabalho, 2000.
} 
premunização desta olerícola foi descontinuada. Outro caso onde a premunização foi descontinuada é o do controle do mosaico do mamoeiro em Taiwan e Hawaii, onde há relatos de aplicação comercial dessa tecnologia (Yeh et al., 1988 e Yeh \& Gonsalves, 1994). Nesse caso, a sua aplicação foi interrompida devido a problemas de quebra de proteção e reversão de sintomas das estirpes fracas (Sheen et al., 1998 e Yeh \& Gonsalves, 1994).

Alguns exemplos experimentais promissores de premunização foram relatados para o controle das viroses causadas pelo Cauliflower mosaic virus em couve (Tomlinson \& Sheperd, 1978); Tobacco mosaic virus em pimenta (Goto et al., 1984); Potato virus Y em fumo (Latorre \& Flores, 1985); Tomato aspermy virus em tomateiro (Kuti \& Moline, 1986); e entre o Beet soilborne mosaic virus e o Beet necrotic yellow vein virus em beterraba açucareira (Mahmood \& Rush, 1999).

Em cucurbitáceas, a premunização passou a ser considerada uma medida importante no controle de viroses a partir dos trabalhos com o mosaico amarelo em abobrinha de moita na França, em Taiwan e na Inglaterra (Lecoq et al.,1991; Walkey et al., 1992 e Wang et al., 1991) e em melão nos EUA (Perring et al., 1995). O seu uso comercial já é conhecido no Hawaii (Cho et al., 1992) e em Israel (Yarden et al., 2000). Nesse último país, essa tecnologia vem sendo aplicada nos últimos 5 anos para o controle do mosaico amarelo em abobrinha de moita, abóbora, melão e melancia. Somente em 1999, quase 800 ha dessas cucurbitáceas premunizadas foram plantadas em Israel, o que viabilizou o desenvolvimento de um equipamento especial para a inoculação massal de mudas, cuja eficiência média foi de 70 a $75 \%$ para melancia, 90 a 95\% para abobrinha de moita e 80 a $85 \%$ para abóbora e melão.

Os trabalhos para o controle do PRSV-W por premunização tiveram início no Estado de São Paulo em 1991, quando foram selecionadas 18 estirpes fracas do vírus em abobrinha de moita (C. pepo) com mosaico, sendo que 
dentre essas, as estirpes PRSV-W-1 e PRSV-W-2 apresentaram maior estabilidade e melhor efeito protetor em plantas mantidas em casa de vegetação (Rezende et al., 1994 e Rezende, 1996). Oefeito protetor dessas estirpes fracas em plantas em campo foi avaliado por Rezende (1996) e Rezende \& Pacheco (1998), com resultados altamente satisfatórios. Plantas de abobrinha de moita premunizadas tiveram ganhos de 344 a $633 \%$ no peso de frutos comerciais, quando comparados com o das plantas infectadas com as estirpes comuns do vírus, e perdas insignificantes, da ordem de $10 \%$, quando comparadas com o peso dos frutos das plantas sadias. A premunização também se mostrou eficiente no controle dessa doença em abóbora rasteira ( $C$. moschata cv. Menina Brasileira) (Rezende et al., 1999). Nesse caso, a tolerância do cultivar Menina Brasileira, juntamente com a premunização, permitiram um melhor controle da doença e ganhos na produção da ordem de $33 \%$. Dias \& Rezende (2000) também verificaram o efeito protetor da estirpe fraca PRSV-W-1 em abóbora híbrida do tipo Tetsukabuto (C. maxima $\times$ C. moschata). Os ganhos na produção das plantas premunizadas foram da ordem de $100 \%$, quando comparados com os daquelas infectadas com a estirpe severa do vírus. Recentemente, Rabelo (2002) selecionou uma estirpe fraca do ZYMV (ZYMV-M) a partir de um isolado exposto à radiação ultravioleta. Essa estirpe fraca foi utilizada concomitantemente com a estirpe fraca PRSV-W-1 para avaliar a dupla premunização para o controle dos mosaicos comum e amarelo em abobrinha de moita em campo. Os resultados foram satisfatórios, tanto no controle dessas duas viroses em abobrinha de moita, como na produção de frutos comerciais.

A premunização para o controle do mosaico causado pelo PRSV-W em plantas de melancia já foi investigada por Dias \& Rezende (2001), porém os resultados não foram tão satisfatórios como os descritos anteriormente, apesar das estirpes fracas terem protegido as plantas contras as estirpes severas. Um dos problemas relatados por esses autores foi a baixa infectividade das estirpes 
fracas do PRSV-W em mudas de melancia. Nem mesmo a realização de duas inoculações em dias consecutivos permitiu obter $100 \%$ de mudas infectadas. Além disso, as plantas premunizadas apresentaram uma redução na produção de 10,8 a 50\% em relação àquelas que permaneceram sadias em campo. Os autores sugeriram que o problema da baixa infectividade das estirpes fracas em melancia pode estar associado à especificidade destas, uma vez que foram selecionadas em plantas do gênero Cucurbita. Caso de especificidade de estirpes fracas de vírus foi constatado no controle da tristeza dos citros por premunização (Costa \& Müller, 1980 e Müller, 1972). Nesse caso, entretanto, a especificidade estava associada com a severidade dos sintomas causados pelas estirpes fracas. Os autores verificaram que estirpes fracas obtidas de plantas de limão Galego foram fracas para esta variedade, enquanto que as estirpes fracas obtidas de laranja Pêra e de pomelos, de uma maneira geral, induziram sintomas fortes em limão Galego, não se mostrando adequadas para serem utilizadas na premunização deste último. De forma similar, as melhores estirpes fracas para laranja Pêra foram obtidas da própria variedade.

Valkonen et al. (2002) estudaram a proteção entre estirpes do Potato virus $A$ (PVA) originárias de batata (U, M, Can e Sab) e de fumo (Ali, B11, Dat e 716/12) em plantas de fumo. Os autores notaram que estirpes do PVA obtidas de fumo foram capazes de infectar plantas previamente infectadas com qualquer estirpe do vírus originária de batata. Em teste recíproco, as estirpes do PVA de batata não quebraram a proteção das de fumo infectadas com as estirpes do vírus obtidas desta espécie.

Quanto à redução na produção de plantas de melancia premunizadas, Dias \& Rezende (2001) não propuseram qualquer sugestão para explicar o fato. Sabe-se que uma pequena redução na produção de plantas premunizadas é esperada, pois se tratam de plantas infectadas com vírus. Rezende \& Pacheco (1998), como citado anteriormente, verificaram uma redução de $10 \%$ na produção de frutos de plantas de abobrinha de moita 'Caserta' premunizadas 
com estirpes fracas, quando comparadas com plantas sadias. Lecoq et al. (1991) verificaram caso semelhante no controle do ZYMV por premunização, quando detectaram redução de $11 \%$ no peso de frutos por planta de abobrinha de moita premunizada, em relação ao daquelas sadias. Pacheco (2002), estudando o efeito da infecção com as estirpes fracas do PRSV-W em plantas de abobrinha de moita 'Caserta' e de melancia 'Crimson Sweet', aos 40 dias após a inoculação, verificou uma redução de 1,7 a 12,4\% na biomassa das plantas premunizadas com as estirpes fracas. 


\section{MATERIAL E MÉTODOS}

\subsection{Plantas-teste}

Neste trabalho foram utilizadas plantas de melancia (Citrullus lanatus) cv. Crimson Sweet e de abobrinha de moita (Cucurbita pepo) cv. Caserta. Para os testes em casa de vegetação, as plantas foram obtidas em vasos de alumínio contendo uma mistura de terra e esterco, colocando três sementes por vaso e, por ocasião do desbaste, foram deixadas duas plantas em cada vaso. Estas plantas foram mantidas em casa de vegetação, adubando-as regularmente com sulfato de amônio. Para os testes em campo, as plantas de melancia foram obtidas em bandeja de isopor de 72 células, contendo substrato Plantmax Hortaliças HA da Eucatex Agro. As mudas foram mantidas sob condições de telado até o transplante para o campo experimental, sendo regadas, uma a duas vezes, com solução 1\% de sulfato de amônio.

\subsection{Estirpes do vírus}

Foram utilizadas as duas estirpes fracas, PRSV-W-1 e PRSV-W-2, selecionadas por Rezende et al. (1994) a partir de bolhas de folhas de abobrinha de moita com mosaico, e uma estirpe fraca (PRSV-W-3) selecionada em plantas de melancia infectadas com isolados comuns do PRSV-W, como descrito no item 4.1. Como controle, foi utilizada uma estirpe severa do PRSVW, oriunda de Campinas/SP (PRSV-W-C). As estirpes foram mantidas, separadamente, em abobrinha de moita e em melancia, sob condições de casa de vegetação. Com a finalidade de manter fontes de inóculo de boa qualidade, 
as estirpes foram freqüentemente transmitidas mecanicamente para novas plantas de abobrinha de moita e de melancia.

\subsection{Inoculação mecânica}

A inoculação das plantas-teste foi realizada macerando-se folhas de abobrinha de moita ou de melancia infectadas com as estirpes do vírus, separadamente, em almofariz, na presença de tampão fosfato de potássio 0,02 $\mathrm{M}, \mathrm{pH}$ 7,0, contendo sulfito de sódio 0,02 M. Os extratos obtidos foram inoculados mecanicamente em folhas cotiledonares das plantas-teste, previamente polvilhadas com carborundum, por meio de fricção das folhas com o dedo indicador ou o pistilo, usado na maceração, umedecido com o inóculo, passando-os duas vezes sobre cada cotilédone. Em seguida, as folhas foram lavadas com água para remover o excesso de inóculo e de abrasivo. As plantas foram mantidas em casa de vegetação para observação dos sintomas.

\subsection{Avaliação de sintomas}

Para a avaliação dos sintomas utilizou-se de uma escala de notas, conferindo nota zero, para plantas sem sintomas perceptíveis; nota um, para plantas com sintomas de mosaico ou clorose pouco evidentes, sem deformações foliares e bom desenvolvimento; nota dois, para aquelas com sintomas de mosaico leve nas folhas novas ou encarquilhamento e leve clorose nas folhas localizadas no ápice dos ramos, não comprometendo o desenvolvimento; nota três, para as plantas com sintomas intermediários de mosaico ou clorose e encarquilhamento em boa parte do ápice dos ramos, provocando sensível atraso no desenvolvimento; nota quatro, para aquelas com sintomas de mosaico severo ou clorose e encarquilhamento nos ponteiros de todos os ramos, afetando acentuadamente o desenvolvimento das plantas; e nota cinco, para aquelas com sintomas de mosaico severo ou clorose e 
encarquilhamento generalizado em todos os ramos, causando definhamento ou até a morte das plantas. Essa escala de notas foi utilizada tanto para a avaliação da proteção em casa de vegetação e em campo, como também para a avaliação da contaminação com outros vírus no final do teste de proteção em campo.

\subsection{Superinoculação}

Superinoculação, também chamada de inoculação de desafio, é a inoculação de plantas já infectadas com outra estirpe do mesmo vírus, geralmente a estirpe fraca. A superinoculação, quando necessária, foi feita mecanicamente, conforme descrito anteriormente, porém em folhas expandidas das plantas, diferentes daquelas da primeira inoculação. A superinoculação foi avaliada, a partir de vinte dias da sua realização, com base na manifestação de sintomas severos nas plantas desafiadas, sendo confirmada, no final do experimento, com o teste de recuperação.

\subsection{Teste de recuperação}

A confirmação da infecção das plantas de melancia com as estirpes fracas e severas do PRSV-W foi feita através do teste de recuperação da estirpe do vírus para plantas de abobrinha de moita (C. pepo cv. Caserta). Folhas expandidas das extremidades dos ramos de plantas de melancia, premunizadas com as estirpes fracas e superinoculadas, foram coletadas, após vinte a vinte e cinco dias da segunda superinoculação ou no fim da colheita, no caso do experimento em campo. Essas folhas, devidamente individualizadas e identificadas, foram maceradas e os extratos resultantes foram inoculados mecanicamente em folhas cotiledonares de plantas de abobrinha de moita 'Caserta', que apresentam reação diferencial para as estirpes fracas e severas do PRSV-W. As avaliações do teste de recuperação foram feitas com base na 
manifestação de sintomas, sendo confirmadas com o teste serológico de PTAELISA.

\subsection{PTA-ELISA}

A detecção de infecção com estirpes do PRSV-W em plantas de melancia e de abobrinha de moita foi feita por meio do teste serológico de ELISA ("Enzyme Linked Immunosorbent Assay") do tipo PTA ("Plate Trapped Antigen") (Mowat \& Dawson, 1987), com algumas modificações. Inicialmente as amostras das plantas a serem analisadas foram maceradas individualmente em tampão de carbonato de sódio $\left(0,015 \mathrm{M} \mathrm{Na}_{2} \mathrm{CO}_{3}, 0,035 \mathrm{M} \mathrm{NaHCO}_{3}, 0,003 \mathrm{M}\right.$ $\mathrm{NaN}_{3}, 1,0 \mathrm{~L} \mathrm{H} \mathrm{H}_{2} \mathrm{O}, \mathrm{pH} 9,6$ ), na diluição aproximada de 1:20. A seguir, foram adicionados $100 \mu \mathrm{L}$ dos extratos de cada amostra, nos respectivos pocinhos, usando dois pocinhos por amostra. Em cada placa foram utilizados um controle positivo e um negativo, que correspondiam a plantas infectadas com a estirpe severa do PRSV-W e plantas sadias, respectivamente. A placa foi incubada por $1,5 \mathrm{~h}$ a $37^{\circ} \mathrm{C}$ e depois lavada trêsvezes consecutivas com PBS-Tween $\left(0,0015 \mathrm{M} \mathrm{KH}_{2} \mathrm{PO}_{4}, \quad 0,14 \mathrm{M} \mathrm{NaCl}, \quad 0,004 \mathrm{M} \mathrm{Na}_{2} \mathrm{HPO}_{4}, \quad 0,003 \mathrm{M} \mathrm{KCl}, \quad 0,003 \quad \mathrm{M}\right.$ $\mathrm{NaN}_{3}, 1,0 \mathrm{~L} \mathrm{H} \mathrm{O}, \mathrm{pH} 7,4+0,5 \mathrm{~mL}$ Tween 20). Foram adicionados $100 \mu \mathrm{L}$ de antissoro produzido em coelho, diluído em tampão Tris- $\mathrm{HCL}(0,2 \mathrm{M}$ Tris- $\mathrm{HCl}$, $0,15 \mathrm{M} \mathrm{NaCl}, 1,0 \mathrm{~L} \mathrm{H} \mathrm{H}_{2} \mathrm{O}, \mathrm{pH}$ 7,2), na diluição de 1:1000, em cada pocinho da placa de ELISA. Depois de um período de incubação de $1,5 \mathrm{~h}$, a $37^{\circ} \mathrm{C}$, a placa foi novamente lavada três vezes com PBS-Tween. Foram adicionados $100 \mu \mathrm{L}$ da IgG conjugada com fosfatase alcalina (SIGMA A-9171), diluída 1:34.000 em tampão Tris-HCL, em cada pocinho. A placa foi novamente incubada por $1,5 \mathrm{~h}$, a $37^{\circ} \mathrm{C}$. Depois de lavada como anteriormente, foram colocados $100 \mu \mathrm{L}$ de $\rho$ fosfato de nitrofenil (SIGMA N-9389), diluído em tampão dietanolamina (97 mL dietanolamina, 0,003 $\mathrm{M} \mathrm{NaN}_{3}, 1,0 \mathrm{~L} \mathrm{H}_{2} \mathrm{O}$, pH 9,8), em cada pocinho. A placa foi incubada àtemperatura ambiente, no escuro, onde ocorreu a reação enzimática (30 a 60 minutos). A absorbância de cada um dos pocinhos foi medida no leitor 
de ELISA, da marca Metertech $\Sigma$ 960, utilizando-se filtro de $405 \mathrm{~nm}$. A reação foi considerada positiva quando o valor médio da absorbância excedia em três vezes o valor médio da absorbância do extrato da planta sadia. O teste de PTAELISA foi utilizado para verificar a infectividade das estirpes fracas do PRSV-W em plantas de melancia e confirmar a presença das estirpes fracas nas plantas fonte das mesmas, utilizando-se antissoro policlonal específico para o vírus, disponível no Laboratório de Virologia do Departamento de Entomologia, Fitopatologia e Zoologia Agrícola da ESALQ. Foi também usado para detectar a presença de vírus contaminantes no experimento em campo. Neste caso, foram utilizados antissoros contra o CMV e o ZYMV, também produzidos no Laboratório de Virologia da ESALQ; além do ZLCV, gentilmente cedido pelo Dr. Antônio C. de Ávila, EMBRAPA/CNPH.

\subsection{Seleção de estirpes fracas do PRSV-W a partir de bolhas de folhas de melancia com mosaico}

$\mathrm{Na}$ tentativa de encontrar estirpes fracas mais infectivas, bolhas foram retiradas de folhas de plantas de melancia com mosaico, naturalmente infectadas em campo, coletadas em uma propriedade localizada no município de Tupã-SP. Do centro de cada bolha foi retirado um disco de $5 \mathrm{~mm}$ de diâmetro. Estes discos foram colocados individualmente na superfície áspera de etiquetas plásticas, utilizadas para identificação de vasos, na presença de uma a duas gotas de tampão fosfato, e macerados com outra etiqueta para extração do inóculo viral. Cada inóculo foi aplicado individualmente em folhas cotiledonares de uma planta de abobrinha de moita 'Caserta'. A inoculação foi feita esfregando levemente a etiqueta contendo o inóculo na superfície do cotilédone previamente polvilhado com carborundum. Após a inoculação, as plantas foram lavadas para retirar o excesso de inóculo e de abrasivo e mantidas em casa de vegetação. As plantas inoculadas foram avaliadas com base na manifestação e intensidade dos sintomas. Plantas com sintomas 
severos de mosaico foram descartadas. Plantas sem sintomas e que foram positivas no teste serológico de PTA-ELISA, com o antissoro contra o PRSV-W, foram selecionadas como portadoras de possíveis estirpes fracas do vírus.

\subsection{Teste de infectividade das estirpes fracas do PRSV-W}

Foi comparada a infectividade das estirpes fracas PRSV-W-1 e PRSV-W2, com a da estirpe fraca selecionada de bolhas de folhas de melancia com mosaico (PRSV-W-3), quando inoculadas mecanicamente em plantas-teste de melancia "Crimson Sweet". Além da origem das estirpes fracas (abobrinha de moita vs melancia), também foram avaliados os efeitos da origem dos inóculos das estirpes fracas (abobrinha de moita vs melancia); da concentração dos inóculos e do estádio de desenvolvimento inicial das plantas de melancia no momento da inoculação na infectividade com as estirpes fracas. A idade das plantas doadoras de inóculos das estirpes fracas foi ao redor de 10 a 14 e 14 a 20 dias após a inoculação, no verão e no inverno respectivamente, o que corresponde ao período em que foi constatada a maior concentração das estirpes fracas em abobrinha de moita e em melancia (Pacheco, 2002). Como controle, em todos os testes, foi usada a estirpe severa PRSV-W-C.

Com a finalidade de ajustar a concentração dos inóculos, dois testes preliminares de infectividade foram realizados. No primeiro, retiraram-se discos foliares de plantas de abobrinha de moita infectadas com as três estirpes fracas e com a estirpe severa PRSV-W-C. Esses discos, agrupados em número de 2, 4, 6 e 8, foram macerados em almofariz, juntamente com $2 \mathrm{~mL}$ de tampão fosfato. Os extratos obtidos foram inoculados separadamente em plantas de melancia 'Crimson Sweet', no estádio cotiledonar. A inoculação mecânica foi feita com o dedo indicador. As avaliações da infecção das plantas de melancia foram feitas com base em sintomas e através de PTA-ELISA. O segundo teste preliminar foi feito de forma semelhante ao anterior, alterando o número de 
discos foliares para 2, 4, 8 e 16, desta vez retirados de plantas de melancia infectadas com as mesmas estirpes do vírus.

Os testes definitivos de infectividade das estirpes fracas foram realizados retirando-se discos foliares de plantas de abobrinha de moita ou de melancia infectadas com as três estirpes fracas e com a estirpe severa de Campinas. Esses discos, agrupados em número de 4, 8, 12 e 16 foram macerados em almofariz, juntamente com $2 \mathrm{~mL}$ de tampão fosfato. Os extratos obtidos foram inoculados separadamente em plantas de melancia 'Crimson Sweet', no estádio cotiledonar. A inoculação mecânica foi feita com o pistilo de maceração. As avaliações da infecção das plantas de melancia foram feitas com base em sintomas e através de PTA-ELISA.

Com a finalidade de avaliar o efeito da pressão de fricção, foram realizados testes de infectividade, usando as mesmas estirpes nas concentrações descritas acima. A inoculação mecânica foi realizada com o dedo indicador, procurando aumentar a força de fricção em relação aos testes preliminares de infectividade, também realizados com o dedo indicador. As avaliações foram feitas como descritas anteriormente.

Para a determinação da idade ideal das mudas de melancia para a inoculação com as estirpes fracas foram comparados os seguintes estádios de desenvolvimento: I) estádio de folha cotiledonar, sem a formação da primeira folha verdadeira; II) estádio de duas folhas verdadeiras, estando a segunda parcialmente expandida; III) estádio de três a quatro folhas verdadeiras, estando a quarta folha parcialmente expandia; e IV) estádio de cinco a sete folhas verdadeiras. A inoculação com as estirpes fracas foi feita mecanicamente, com o dedo indicador, utilizando inóculos extraídos de 12 discos foliares, de $1 \mathrm{~cm}$ de diâmetro, macerados em $2 \mathrm{~mL}$ de tampão fosfato. $A$ avaliação das plantas foi feita, novamente, através da expressão de sintomas e do teste serológico de PTA-ELISA. 


\subsection{Teste de proteção da estirpe fraca obtida de bolhas de folhas de melancia em casa de vegetação}

Plantas de melancia 'Crimson Sweet', mantidas em casa de vegetação, foram mecanicamente inoculadas com a estirpe fraca PRSV-W-3 selecionada de bolhas de folhas de melancia com mosaico. Essa inoculação foi feita no estádio de folha cotiledonar. Dez dias após a inoculação, as plantas foram indexadas por PTA-ELISA para confirmar a infecção com a estirpe fraca. A primeira inoculação de desafio com a estirpe severa PRSV-W-C foi feita 15 dias após a inoculação de proteção, em duas folhas expandidas do ponteiro das plantas. Planta sadia, da mesma idade, foi inoculada com a estirpe PRSV-W-C como controle do inóculo do desafio. A segunda superinoculação foi realizada 10 dias após a primeira, em metade das plantas já desafiadas, novamente inoculando uma planta sadia como controle do inóculo. As avaliações foram feitas com base na manifestação de sintomas e no teste de recuperação das estirpes do vírus para plantas de abobrinha de moita.

\subsection{Teste de proteção das estirpes fracas do PRSV-W em campo}

Um teste de proteção de melancia em campo foi realizado em uma área de propriedade do Sr. Humberto Calderan, no município de Anhembi-SP, avaliando os seguintes tratamentos: A) plantas premunizadas com a estipe fraca PRSV-W-1; B) plantas premunizadas com a estirpe fraca PRSV-W-2; C) plantas premunizadas com a estirpe fraca PRSV-W-3; D) plantas sadias expostas à infecção natural. $O$ delineamento utilizado foi 0 de blocos casualizados, com 15 repetições, sendo a parcela constituída por uma planta. As mudas foram obtidas em bandejas de 72 células sob condições protegidas de telado, sendo feita a semeadura no dia 14 de julho de 2000. Essas mudas foram inoculadas três vezes (dias 14, 16 e 21 de agosto) com as três estirpes fracas obtidas de plantas de abobrinha de moita sabidamente infectadas, de acordo com os tratamentos. As mudas foram transplantadas, dia 25 de agosto, 
em covas preparadas com adubo mineral e orgânico (1,5 a 2,0 kg por cova), colocando-se três plantas por cova. Dezoito dias após a inoculação (11 de setembro), amostras de folhas de todas as plantas inoculadas e transplantadas foram coletadas, separadamente, para confirmar a infecção com as estirpes fracas, através do PTA-ELISA. As plantas com resultado negativo no PTAELISA e/ou aquelas menos vigorosas foram descartadas no desbaste, realizado dia 15 de setembro. Foi deixada uma planta infectada e bem vigorosa por cova. As plantas premunizadas foram mecanicamente desafiadas com a estirpe severa PRSV-W-C aos 25 e 45 dias após o transplante, precisamente nos dias 10 e 30 de outubro. Duas plantas sadias, da bordadura, foram inoculadas com o mesmo inóculo do desafio a fim de servirem como controle. A contaminação com outros vírus (CMV, ZLCV e ZYMV) foi monitorada através do acompanhamento dos sintomas em três visitas feitas nos dias 10 de outubro e 13 de novembro, e por PTA-ELISA com amostras coletadas no final do experimento, dia 15 de dezembro. A produção das plantas contaminadas com um ou mais desses vírus, e que apresentavam nota igual ou maior que três na avaliação dos sintomas no início da colheita dos frutos, dia 13 de novembro, foi desconsiderada na análise final. A proteção das plantas de melancia foi avaliada através de observações periódicas de sintomas, correspondente às visitas de monitoramento e, principalmente, por meio de teste de recuperação das estirpes presentes nas mesmas para plantas de abobrinha de moita, no final do experimento, com amostras coletadas no dia 15 de dezembro. Por ocasião da colheita, realizada de 13 de novembro a 15 de dezembro, foram feitas avaliações quantitativas do número e peso dos frutos colhidos por planta. Foram feitas também avaliações qualitativas dos frutos produzidos pelas plantas dos diferentes tratamentos, verificando a presença de defeitos, e quantificando o brix da polpa do fruto com o uso de um refratômetro portátil. 


\subsection{Análise estatística}

A análise estatística da infectividade das três estirpes fracas e da estirpe severa do PRSV-W em plantas de melancia, inoculadas em quatro concentrações com o auxílio do pistilo de maceração, considerando o delineamento em blocos no esquema fatorial $4 \times 4$, foi realizada com o auxílio do programa GLM ("General Linear Model") do sistema estatístico SAS ("Statistical Analysis System"). As médias foram comparadas pelo teste de Tukey ao nível de significância de 5\%. Os dados de produção do experimento em campo foram analisados estatisticamente com o auxílio do mesmo programa, desta vez ajustado para a ocorrência de dados desbalanceados (Sas Institute, 1990). As médias também foram comparadas pelo teste de Tukey ao nível de significância de 5\%. 


\section{RESULTADOS}

\subsection{Estirpe fraca do PRSV-W obtida a partir de bolhas de folhas de melancia com mosaico}

Foram obtidos inóculos de 30 discos de bolhas retiradas de folhas de plantas de melancia naturalmente infectadas com o PRSV-W em campo. Destes, 28 causaram sintomas severos quando inoculados em abobrinha de moita 'Caserta'. Dois induziram sintomas fracos e imperceptíveis em abobrinha de moita. Extratos destas plantas reagiram positivamente com 0 antissoro contra o PRSV-W no teste de PTA-ELISA. Uma estirpe mostrou-se estável e foi denominada PRSV-W-3, sendo mantida em plantas de abobrinha de moita 'Caserta' e em melancia 'Crimson Sweet'. A outra estirpe, depois de algum tempo, intensificou os sintomas nas plantas-teste e foi descartada.

\subsection{Infectividade das estirpes fracas do PRSV-W}

Os resultados do primeiro teste preliminar de infectividade das estirpes fracas do PRSV-W, com inóculos obtidos a partir de 2, 4, 6 e 8 discos foliares de plantas de abobrinha de moita infectadas, separadamente, com as respectivas estirpes, estão apresentados na Tabela 1. De forma geral, notou-se uma progressão do número de plantas infectadas com 0 aumento da concentração dos inóculos das estirpes fracas PRSV-W-2 e PRSV-W-3, tendo elevado de $0 \%$ e 16,7\% nas inoculações com extratos de 2 discos foliares para $50 \%$ e $66,7 \%$ naquelas com extratos de 8 discos, respectivamente. No caso da estirpe fraca PRSV-W-1 os resultados não mostraram a mesma tendência. Notou-se uma progressão inicial na infectividade dos inóculos obtidos de 2 e 4 
discos foliares, de $16,7 \%$ para $83,3 \%$. No entanto, com extratos de 8 discos houve uma redução para $50 \%$ de infectividade. Apesar da tendência de aumento da infectividade com a concentração do inóculo, não foi possível infectar todas as plantas inoculadas com as estirpes fracas. A infectividade da estirpe severa PRSV-W-C, usada como controle, foi de $100 \%$ em todas as concentrações de inóculos.

Tabela 1. Infectividade das estirpes fracas (PRSV-W-1, PRSV-W-2, PRSV-W-3) e severa do vírus (PRSV-W-C) em plantas de melancia 'Crimson Sweet', inoculadas com extratos de 2, 4, 6 e 8 discos foliares de plantas de abobrinha de moita infectadas com as respectivas estirpes.

\begin{tabular}{lcccc}
\hline Estirpe & \multicolumn{4}{c}{ Número de discos foliares } \\
\cline { 2 - 5 } & 2 & 4 & 6 & 8 \\
\hline PRSV-W-1 & $1 / 6^{*}$ & $5 / 6$ & $5 / 6$ & $3 / 6$ \\
PRSV-W-2 & $0 / 6$ & $1 / 6$ & $1 / 6$ & $3 / 6$ \\
PRSV-W-3 & $1 / 6$ & $2 / 6$ & $2 / 6$ & $4 / 6$ \\
PRSV-W-C & $6 / 6$ & $6 / 6$ & $6 / 6$ & $6 / 6$ \\
\hline
\end{tabular}

* Número de plantas infectadas/número de plantas inoculadas

O segundo experimento preliminar de infectividade, com inóculos obtidos de 2, 4, 8 e 16 discos foliares de plantas de melancia, apresentou resultados semelhantes ao anterior, como pode ser observado na Tabela 2. Notou-se uma progressão da infectividade das estipes PRSV-W-1 e PRSV-W-2 com o aumento da concentração de inóculo, passando de $0 \%$ e 33,3\% nas inoculações com extratos de 2 discos foliares, para 33,3\% e 83,3\% naquelas com extratos de 16 discos foliares, respectivamente. No caso da estirpe PRSVW-3, a infectividade passou de $50 \%$ com extrato de 2 discos para $100 \%$ naquela com 8 discos foliares. Com o aumento da concentração do inóculo, 
entretanto a infectividade dessa estirpe reduziu para 33,3\%. Apesar da oscilação do número de plantas infectadas em função da concentração dos inóculos, as estirpes fracas não causaram infecção de 100\% das plantas, com exceção à estirpe PRSV-W-3 na inoculação com extratos de 8 discos foliares. Novamente, a estirpe severa apresentou $100 \%$ de infectividade na maioria das diluições, exceto para o inóculo extraído de 2 discos foliares, onde ocorreu infectividade de $66,7 \%$.

Tabela 2. Infectividade das estirpes fracas (PRSV-W-1, PRSV-W-2, PRSV-W-3) e severa do vírus (PRSV-W-C) em plantas de melancia 'Crimson Sweet', inoculadas com extratos de 2, 4, 8 e 16 discos foliares de plantas de melancia infectadas com as respectivas estirpes.

\begin{tabular}{lcccc}
\hline Estirpe & \multicolumn{4}{c}{ Número de discos foliares } \\
\cline { 2 - 5 } & 2 & 4 & 8 & 16 \\
\hline PRSV-W-1 & $0 / 6^{*}$ & $0 / 6$ & $1 / 6$ & $2 / 6$ \\
PRSV-W-2 & $2 / 6$ & $3 / 6$ & $3 / 6$ & $5 / 6$ \\
PRSV-W-3 & $3 / 6$ & $3 / 6$ & $6 / 6$ & $2 / 6$ \\
PRSV-W-C & $4 / 6$ & $6 / 6$ & $6 / 6$ & $6 / 6$ \\
\hline
\end{tabular}

* Número de plantas infectadas/número de plantas inoculadas

Com base nesses testes preliminares, foram realizados diversos experimentos independentes para comparar a infectividade das estirpes fracas em função da concentração e da origem do inóculo (abobrinha de moita vs. melancia), porém com pequena modificação no procedimento de inoculação mecânica. Os extratos para inoculação foram obtidos de 4, 8, 12 e 16 discos foliares, respectivamente. As inoculações em plantas de melancia 'Crimson Sweet' foram feitas com o auxílio do pistilo de maceração, umedecido no inóculo e friccionado na folha cotiledonar contendo abrasivo, ao invés do dedo 
indicador. Os resultados desses testes estão apresentados nas Tabelas 3 e 4 . De modo geral, a infectividade das estirpes fracas em mudas de melancia nesses testes foi, em média, da ordem de $60 \%$ a $92 \%$, não apresentando, ao contrário dos testes anteriores, grandes oscilações. A infectividade das estirpes fracas também não mostrou tendência de progressão com o aumento da concentração do inóculo. A utilização de inóculos das estirpes fracas extraídos de abobrinha de moita (Tabela 3) ou de melancia (Tabela 4), não parece ter efeito significativo na infectividade em plantas de melancia. $A$ análise estatística dos resultados desses testes mostrou que não houve interação significativa das estirpes do PRSV-W com as diferentes concentrações. Não se verificou o efeito da origem das estirpes fracas, visto que a infectividade das três estirpes fracas não diferiu significativamente entre si, tendo diferido, entretanto, da infectividade da estirpe severa, ao nível de $5 \%$ de significância. Apesar de, na soma dos testes, as estirpes fracas não terem infectado todas as plantas-teste, em vários casos este feito foi verificado. A infectividade média das estirpes fracas nesses testes foi bem acima daquela obtida nos testes preliminares. Por outro lado, a infectividade da estirpe severa manteve-se em 100\% em todos os testes, independente da concentração do inóculo.

$\mathrm{Na}$ Tabela 5 estão apresentados os resultados de dois testes de infectividade das estirpes fracas inoculadas com o dedo indicador, aumentando a pressão de friçção. A análise estatística desses dados não foi feita por causa do número de testes (2) realizados. Notou-se que as três estirpes fracas apresentaram alta infectividade, atingindo 100\% nas concentrações de 8 e 12 discos foliares. No caso dos inóculos preparados com 16 discos foliares, a infectividade manteve-se $100 \%$, exceto para a estirpe fraca PRSV-W-3, que foi reduzida para $87,5 \%$. Nas inoculações com extratos de 4 discos foliares, a infectividade das estirpes fracas PRSV-W-1 e PRSV-W-2 foi menor do que nas outras concentrações, sendo de $83,3 \%$ e $75 \%$, respectivamente, exceto para a estirpe fraca PRSV-W-3 que obteve $100 \%$ nesta concentração. A estirpe severa mais uma vez infectou todas as plantas testadas. 
Tabela 3. Infectividade das estirpes fracas (PRSV-W-1, PRSV-W-2, PRSV-W-3) e severa (PRSV-W-C) em plantas de melancia 'Crimson Sweet', inoculadas mecanicamente com o auxílio do pistilo de maceração, com extratos de 4, 8, 12 e 16 discos foliares de plantas de abobrinha infectadas com as respectivas estirpes.

\begin{tabular}{|c|c|c|c|c|c|c|c|c|c|c|}
\hline \multirow[t]{3}{*}{ Estirpe } & \multicolumn{10}{|c|}{ Número de discos foliares } \\
\hline & \multicolumn{5}{|c|}{4} & \multicolumn{5}{|c|}{8} \\
\hline & $\mathrm{T} 1^{*}$ & $\mathrm{~T} 2$ & T3 & T4 & $\mathrm{S}(\%)$ & T1 & $\mathrm{T} 2$ & T3 & T4 & $\mathrm{S}(\%)$ \\
\hline PRSV-W-1 & $3 / 6^{* *}$ & $6 / 6$ & $5 / 6$ & $6 / 6$ & $\begin{array}{c}20 / 24 \\
(83,3) a^{\star \star \star}\end{array}$ & $5 / 6$ & $1 / 2$ & $5 / 6$ & $5 / 5$ & $\begin{array}{c}16 / 19 \\
(84,2) \mathrm{a}\end{array}$ \\
\hline PRSV-W-2 & $4 / 6$ & $6 / 6$ & $5 / 6$ & $4 / 5$ & $\begin{array}{c}19 / 23 \\
(82,6) a\end{array}$ & $6 / 6$ & $6 / 6$ & $5 / 6$ & $5 / 6$ & $\begin{array}{c}22 / 24 \\
(91,7) \mathrm{a}\end{array}$ \\
\hline PRSV-W-3 & $5 / 6$ & $6 / 6$ & $6 / 6$ & $4 / 6$ & $\begin{array}{c}21 / 24 \\
(87,5) a\end{array}$ & $4 / 6$ & $6 / 6$ & $6 / 6$ & $4 / 6$ & $\begin{array}{c}20 / 24 \\
(83,3) \mathrm{a}\end{array}$ \\
\hline PRSV-W-C & $3 / 3$ & $5 / 5$ & $6 / 6$ & $6 / 6$ & $\begin{array}{r}20 / 20 \\
(100) b\end{array}$ & $5 / 5$ & $6 / 6$ & $6 / 6$ & $6 / 6$ & $\begin{array}{l}23 / 23 \\
(100) b\end{array}$ \\
\hline \multirow[t]{3}{*}{ Estirpe } & \multicolumn{10}{|c|}{ Número de discos foliares } \\
\hline & \multicolumn{5}{|c|}{12} & \multicolumn{5}{|c|}{16} \\
\hline & $\mathrm{T} 1$ & T2 & T3 & T4 & $\mathrm{S}(\%)$ & $\mathrm{T} 1$ & $\mathrm{~T} 2$ & T3 & $\mathrm{T} 4$ & $\mathrm{~S}(\%)$ \\
\hline PRSV-W-1 & $5 / 6$ & $4 / 5$ & $4 / 6$ & $5 / 6$ & $\begin{array}{c}18 / 23 \\
(78,3) \mathrm{a}\end{array}$ & $4 / 6$ & $3 / 4$ & $5 / 6$ & $6 / 6$ & $\begin{array}{c}18 / 22 \\
(81,8) \mathrm{a}\end{array}$ \\
\hline PRSV-W-2 & $4 / 5$ & $4 / 6$ & $3 / 6$ & $6 / 6$ & $\begin{array}{c}17 / 23 \\
(73,9) \mathrm{a}\end{array}$ & $6 / 6$ & $6 / 6$ & $4 / 6$ & $6 / 6$ & $\begin{array}{l}22 / 24 \\
(91.7) \mathrm{a}\end{array}$ \\
\hline PRSV-W-3 & $2 / 6$ & $6 / 6$ & $6 / 6$ & $6 / 6$ & $\begin{array}{c}20 / 24 \\
(83,3) a\end{array}$ & $2 / 6$ & $6 / 6$ & $5 / 6$ & $6 / 6$ & $\begin{array}{c}19 / 24 \\
(79,2) \mathrm{a}\end{array}$ \\
\hline PRSV-W-C & $6 / 6$ & $6 / 6$ & $6 / 6$ & $6 / 6$ & $\begin{array}{r}24 / 24 \\
(100) b \\
\end{array}$ & $6 / 6$ & $6 / 6$ & $6 / 6$ & $6 / 6$ & $\begin{array}{l}24 / 24 \\
(100) b \\
\end{array}$ \\
\hline
\end{tabular}

* T1, T2, T3 e T4 representam os testes de 1 a 4. S corresponde à soma de todos os testes, com porcentagem total de plantas infectadas entre parênteses.

** Número de plantas infectadas/número de plantas inoculadas.

*** Letras iguais na coluna não diferem ao nível de $5 \%$ de significância. 
Tabela 4. hfectividade das estirpes fracas (PRSV-W-1, PRSV-W-2, PRSV-W-3) e severa (PRSV-W-C) em plantas de melancia 'Crimson Sweet', inoculadas mecanicamente com o auxílio do pistilo de maceração, com extratos de 4, 8, 12 e 16 discos foliares de plantas de melancia infectadas com as respectivas estirpes.

\begin{tabular}{|c|c|c|c|c|c|c|c|c|c|c|c|c|}
\hline \multirow[t]{3}{*}{ Estirpe } & \multicolumn{12}{|c|}{ Número de discos foliares } \\
\hline & \multicolumn{6}{|c|}{4} & \multicolumn{6}{|c|}{8} \\
\hline & $\mathrm{T} 1^{*}$ & $\mathrm{~T} 2$ & T3 & $\mathrm{T} 4$ & T5 & S (\%) & $\mathrm{T} 1$ & $\mathrm{~T} 2$ & T3 & $\mathrm{T} 4$ & T5 & $\mathrm{S}(\%)$ \\
\hline $\begin{array}{l}\text { PRSV- } \\
W-1\end{array}$ & $4 / 6^{* \star}$ & $2 / 6$ & $5 / 6$ & $5 / 6$ & $3 / 6$ & $\begin{array}{c}19 / 30 \\
(63,3) a^{\star * *}\end{array}$ & $5 / 5$ & $2 / 6$ & $5 / 6$ & $6 / 6$ & $4 / 6$ & $\begin{array}{c}22 / 29 \\
(75,9) \mathrm{a}\end{array}$ \\
\hline $\begin{array}{l}\text { PRSV- } \\
W-2\end{array}$ & $2 / 5$ & $3 / 5$ & $4 / 6$ & $3 / 5$ & $4 / 6$ & $\begin{array}{c}16 / 27 \\
(59,3) a\end{array}$ & $5 / 6$ & $5 / 6$ & $6 / 6$ & $4 / 5$ & $4 / 6$ & $\begin{array}{c}24 / 29 \\
(82,8) \mathrm{a}\end{array}$ \\
\hline $\begin{array}{l}\text { PRSV- } \\
\text { W-3 }\end{array}$ & $4 / 6$ & $3 / 6$ & $5 / 6$ & $6 / 6$ & $6 / 6$ & $\begin{array}{c}24 / 30 \\
(80,0) a\end{array}$ & $4 / 6$ & $5 / 6$ & $6 / 6$ & $6 / 6$ & $6 / 6$ & $\begin{array}{c}27 / 30 \\
(90,0) \mathrm{a}\end{array}$ \\
\hline $\begin{array}{l}\text { PRSV- } \\
\text { W-C }\end{array}$ & $6 / 6$ & $5 / 5$ & $6 / 6$ & $6 / 6$ & $6 / 6$ & $\begin{array}{r}29 / 29 \\
(100) b\end{array}$ & $6 / 6$ & $6 / 6$ & $6 / 6$ & $5 / 5$ & $6 / 6$ & $\begin{array}{c}29 / 29 \\
(100) \mathrm{b}\end{array}$ \\
\hline \multirow[t]{3}{*}{ Estirpe } & \multicolumn{12}{|c|}{ Número de discos foliares } \\
\hline & \multicolumn{6}{|c|}{12} & \multicolumn{6}{|c|}{16} \\
\hline & T1 & T2 & T3 & $\mathrm{T} 4$ & T5 & S (\%) & $\mathrm{T} 1$ & T2 & T3 & $\mathrm{T} 4$ & T5 & S (\%) \\
\hline $\begin{array}{l}\text { PRSV- } \\
W-1\end{array}$ & $4 / 6$ & $4 / 6$ & $5 / 6$ & $5 / 5$ & $4 / 6$ & $\begin{array}{c}22 / 29 \\
(75,9) \mathrm{a}\end{array}$ & $5 / 6$ & $5 / 6$ & $5 / 6$ & $6 / 6$ & $6 / 6$ & $\begin{array}{c}27 / 30 \\
(90,0) \mathrm{a}\end{array}$ \\
\hline $\begin{array}{l}\text { PRSV- } \\
\text { W-2 }\end{array}$ & $5 / 5$ & $3 / 6$ & $5 / 6$ & $6 / 6$ & $3 / 6$ & $\begin{array}{c}22 / 29 \\
(75,9) \mathrm{a}\end{array}$ & $6 / 6$ & $4 / 6$ & $5 / 6$ & $4 / 4$ & $4 / 6$ & $\begin{array}{c}23 / 28 \\
(82,1) \mathrm{a}\end{array}$ \\
\hline $\begin{array}{l}\text { PRSV- } \\
\text { W-3 }\end{array}$ & $5 / 6$ & $3 / 6$ & $6 / 6$ & $6 / 6$ & $6 / 6$ & $\begin{array}{c}26 / 30 \\
(86,7) \text { a }\end{array}$ & $4 / 5$ & $3 / 5$ & $6 / 6$ & $5 / 5$ & $5 / 6$ & $\begin{array}{c}23 / 27 \\
(85,2) \mathrm{a}\end{array}$ \\
\hline $\begin{array}{l}\text { PRSV- } \\
\text { W-C }\end{array}$ & $5 / 5$ & $6 / 6$ & $6 / 6$ & $6 / 6$ & $6 / 6$ & $\begin{array}{c}29 / 29 \\
(100) b\end{array}$ & $6 / 6$ & $5 / 5$ & $6 / 6$ & $4 / 4$ & $6 / 6$ & $\begin{array}{l}27 / 27 \\
(100) b\end{array}$ \\
\hline
\end{tabular}

* T1, T2, T3 e T4 representam os testes de 1 a 4 . S corresponde à soma de todos os testes, com porcentagem total de plantas infectadas entre parênteses.

** Número de plantas infectadas/número de plantas inoculadas.

${ }^{* \star *}$ Letras iguais na coluna não diferem ao nível de $5 \%$ de significância. 
Tabela 5. Infectividade das estirpes fracas (PRSV-W-1, PRSV-W-2, PRSV-W-3) e severa (PRSV-W-C) em plantas de melancia 'Crimson Sweet', inoculadas mecanicamente, com $\mathrm{o}$ auxílio do dedo indicador $\mathrm{e}$ aumento da pressão de friç̧ão, com extratos de 4, 8, 12 e 16 discos foliares.

\begin{tabular}{|c|c|c|c|c|c|c|c|c|c|c|c|c|}
\hline \multirow[t]{3}{*}{ Estirpe } & \multicolumn{12}{|c|}{ Número de discos foliares } \\
\hline & \multicolumn{3}{|c|}{4} & \multicolumn{3}{|c|}{8} & \multicolumn{3}{|c|}{12} & \multicolumn{3}{|c|}{16} \\
\hline & $\mathrm{T} 1^{*}$ & $\mathrm{~T} 2$ & $\begin{array}{c}S \\
(\%)\end{array}$ & $\mathrm{T} 1$ & T2 & $\begin{array}{c}S \\
(\%)\end{array}$ & $\mathrm{T} 1$ & $\mathrm{~T} 2$ & $\begin{array}{c}S \\
(\%)\end{array}$ & $\mathrm{T} 1$ & T2 & $\begin{array}{c}S \\
(\%)\end{array}$ \\
\hline PRSV-W-1 & $5 / 6^{* *}$ & $5 / 6$ & $\begin{array}{l}10 / 12 \\
(83,3)\end{array}$ & $6 / 6$ & $6 / 6$ & $\begin{array}{l}12 / 12 \\
(100)\end{array}$ & $6 / 6$ & $5 / 5$ & $\begin{array}{l}11 / 11 \\
(100)\end{array}$ & $6 / 6$ & $6 / 6$ & $\begin{array}{l}12 / 12 \\
(100)\end{array}$ \\
\hline PRSV-W-2 & $5 / 6$ & $4 / 6$ & $\begin{array}{c}9 / 12 \\
(75,0)\end{array}$ & $4 / 4$ & $6 / 6$ & $\begin{array}{l}10 / 10 \\
(100)\end{array}$ & $6 / 6$ & $6 / 6$ & $\begin{array}{c}12 / 12 \\
(100)\end{array}$ & $6 / 6$ & $6 / 6$ & $\begin{array}{r}12 / 12 \\
(100)\end{array}$ \\
\hline PRSV-W-3 & $6 / 6$ & $5 / 5$ & $\begin{array}{l}11 / 11 \\
(100)\end{array}$ & $6 / 6$ & $5 / 5$ & $\begin{array}{l}11 / 11 \\
(100)\end{array}$ & $6 / 6$ & $6 / 6$ & $\begin{array}{l}12 / 12 \\
(100)\end{array}$ & $5 / 6$ & $2 / 2$ & $\begin{array}{c}7 / 8 \\
(87,5)\end{array}$ \\
\hline PRSV-W-C & $6 / 6$ & $6 / 6$ & $\begin{array}{l}12 / 12 \\
(100)\end{array}$ & $6 / 6$ & $6 / 6$ & $\begin{array}{r}12 / 12 \\
(100)\end{array}$ & $6 / 6$ & $6 / 6$ & $\begin{array}{l}12 / 12 \\
(100)\end{array}$ & $6 / 6$ & $6 / 6$ & $\begin{array}{r}12 / 12 \\
(100)\end{array}$ \\
\hline
\end{tabular}

* T1 e T2 representam os testes de 1 e 2 . S corresponde à soma dos dois testes, com porcentagem total de plantas infectadas entre parênteses.

** Número de plantas infectadas/número de plantas inoculadas.

Os resultados de dois testes para avaliar o efeito da idade ideal das mudas de melancia na infectividade das estirpe fracas estão apresentados na Tabela 6. A análise estatística não foi feita devido ao pequeno número de testes (2) realizados. De acordo com esses resultados, os diferentes estádios de desenvolvimento não parecem ter afetado significativamente a infectividade das estirpes fracas, a qual variou de $75 \%$ a $100 \%$. Uma exceção a esse caso foi notada na infectividade da estirpe fraca PRSV-W-1 em mudas de melancia no 
estádio cotiledonar (I), a qual foi de $50 \%$. A estirpe severa novamente infectou todas as plantas, independente do estádio de desenvolvimento.

Tabela 6. Infectividade das estirpes fracas (PRSV-W-1, PRSV-W-2, PRSV-W-3) e severa (PRSV-W-C) em mudas de melancia 'Crimson Sweet', em quatro estádios de desenvolvimento, inoculadas mecanicamente com o auxílio do dedo indicador.

\begin{tabular}{|c|c|c|c|c|c|c|c|c|c|c|c|c|}
\hline \multirow[t]{3}{*}{ Estirpe } & \multicolumn{12}{|c|}{ Estádio de desenvolvimento } \\
\hline & \multicolumn{3}{|c|}{$P^{*}$} & \multicolumn{3}{|c|}{ II } & \multicolumn{3}{|c|}{ III } & \multicolumn{3}{|c|}{$\mathrm{IV}$} \\
\hline & $\mathrm{T} 1^{* *}$ & $\mathrm{~T} 2$ & $\begin{array}{l}S \\
(\%)\end{array}$ & $\mathrm{T} 1$ & $\mathrm{~T} 2$ & $\begin{array}{l}S \\
(\%)\end{array}$ & $\mathrm{T} 1$ & $\mathrm{~T} 2$ & $\begin{array}{l}S \\
(\%)\end{array}$ & T1 & $\mathrm{T} 2$ & $\begin{array}{l}S \\
(\%)\end{array}$ \\
\hline PRSV-W-1 & $3 / 6^{* \star *}$ & $3 / 6$ & $\begin{array}{c}6 / 12 \\
(50,0)\end{array}$ & $5 / 6$ & $5 / 6$ & $\begin{array}{l}10 / 12 \\
(83,3)\end{array}$ & $4 / 6$ & $5 / 6$ & $\begin{array}{c}9 / 12 \\
(75,0)\end{array}$ & $5 / 6$ & $6 / 6$ & $\begin{array}{l}11 / 12 \\
(91,7)\end{array}$ \\
\hline PRSV-W-2 & $5 / 6$ & $4 / 5$ & $\begin{array}{c}9 / 11 \\
(81,8)\end{array}$ & $5 / 6$ & $5 / 6$ & $\begin{array}{l}10 / 12 \\
(83,3)\end{array}$ & $6 / 6$ & $6 / 6$ & $\begin{array}{l}12 / 12 \\
(100)\end{array}$ & $4 / 6$ & $6 / 6$ & $\begin{array}{l}10 / 12 \\
(83,3)\end{array}$ \\
\hline PRSV-W-3 & $4 / 5$ & $6 / 6$ & $\begin{array}{l}10 / 11 \\
(90,9)\end{array}$ & $5 / 6$ & $5 / 5$ & $\begin{array}{l}10 / 11 \\
(90,9)\end{array}$ & $4 / 4$ & $5 / 5$ & $\begin{array}{c}9 / 9 \\
(100)\end{array}$ & $6 / 6$ & $5 / 6$ & $\begin{array}{l}11 / 12 \\
(91,7)\end{array}$ \\
\hline PRSV-W-C & $6 / 6$ & $6 / 6$ & $\begin{array}{r}12 / 12 \\
(100)\end{array}$ & $6 / 6$ & $6 / 6$ & $\begin{array}{r}12 / 12 \\
(100)\end{array}$ & $6 / 6$ & $6 / 6$ & $\begin{array}{l}12 / 12 \\
(100)\end{array}$ & $6 / 6$ & $6 / 6$ & $\begin{array}{r}12 / 12 \\
(100)\end{array}$ \\
\hline
\end{tabular}

* Estádios de desenvolvimento: I) folha cotiledonar; II) duas folhas verdadeiras; III) três a quatro folhas verdadeiras; IV) cinco a sete folhas verdadeiras.

** T1 e T2 representam os testes de 1 e 2 . $S$ corresponde à soma dos dois testes, com porcentagem total de plantas infectadas entre parênteses.

*** Número de plantas infectadas/número de plantas inoculadas. 


\subsection{Efeito protetor da estirpe fraca PRSV-W-3 em melancia em casa de vegetação}

Os resultados de dois testes independentes do efeito protetor da estirpe fraca PRSV-W-3 em plantas de melancia 'Crimson Sweet' estão apresentados na Tabela 7. Todas as plantas infectadas com a estirpe fraca PRSV-W-3, confirmadas por meio de PTA-ELISA, ficaram protegidas contra a infecção e/ou manifestação da estirpe severa do vírus (PRSV-W-C), já que nenhuma destas plantas recebeu notas de sintomas iguais ou maiores do que dois. A proteção foi eficiente mesmo quando as plantas foram desafiadas duas vezes com a estirpe severa. As plantas de melancia, inicialmente sadias, quando inoculadas com a estirpe PRSV-W-C receberam notas de sintomas de quatro a cinco. A recuperação da estirpe do vírus das plantas de melancia premunizadas e desafiadas, para plantas de abobrinha de moita, feita aos 45 dias após a premunização, confirmou o efeito protetor da estirpe PRSV-W-3. Em nenhuma das plantas de abobrinha de moita notou-se sintomas que receberam notas acima de dois, não tendo sido recuperada a estirpe severa do PRSV-W utilizada na superinoculação. A confirmação da infecção destas plantas foi feita por PTAELISA. 
Tabela 7. Reação de plantas de melancia 'Crimson Sweet' premunizadas com a estirpe fraca PRSV-W-3 e desafiadas com a estirpe severa PRSV-W$C$, em dois testes independentes realizados em casa de vegetação.

\begin{tabular}{lcc}
\hline Tratamento & \multicolumn{2}{l}{$\begin{array}{l}\text { Número de plantas testadas / número de } \\
\text { plantas com sintomas severos de } \\
\text { mosaico }\end{array}$} \\
\cline { 2 - 3 } & \multicolumn{2}{c}{ Teste 1} \\
\hline PRSV-W-3 + PRSV-W-C & $10 / 0$ & Teste 2 \\
PRSV-W-3 + PRSV-W-C (duas vezes) & $10 / 0$ & $10 / 0$ \\
Sadia + PRSV-W-C & $2 / 2$ & $10 / 0$ \\
Sadia & $1 / 0$ & $2 / 2$ \\
\hline
\end{tabular}

\subsection{Efeito protetor das estirpes fracas do PRSV-W em melancia em campo}

Após a realização do desbaste, o número de plantas comprovadamente infectadas com as estirpes fracas PRSV-W-1, PRSV-W-2 e PRSV-W-3 foi de 13, 14 e 10, respectivamente, as quais foram acompanhadas até o final do experimento. $\mathrm{Na}$ Tabela 8 estão apresentados os resultados das leituras dos sintomas das plantas premunizadas e não premunizadas em diferentes épocas. Por ocasião do primeiro desafio, dia 10 de outubro, todas as plantas de melancia sabidamente premunizadas não apresentavam sintomas com notas iguais ou maiores do que três. Entretanto, duas plantas não premunizadas apresentavam sintomas, caracterizados por mosaico severo e deformações no ápice dos ramos e por isso receberam nota superior a três. Nas observações de 30 de outubro, quando foi feito o segundo desafio, constatou-se apenas duas plantas premunizadas (14,3\%) com a estirpe PRSV-W-2 apresentando sintomas, caracterizados por sintomas de mosaico e/ou clorose severos e até necrose nas extremidades dos ramos. Na testemunha não premunizada, três plantas (20\%) apresentavam esses sintomas. As observações de 13 de 
novembro mostraram que $7,7 \%, 21,4 \%$ e $10 \%$ das plantas premunizadas com as estirpes fracas PRSV-W-1, PRSV-W-2 e PRSV-W-3, respectivamente, apresentavam sintomas acentuados, recebendo notas iguais ou maiores do que três. No tratamento com plantas não premunizadas observou-se um aumento das plantas sintomáticas para $26,7 \%$. Nas observações de 20 de novembro, os três tratamentos com plantas premunizadas apresentavam 30,8\%, 35,7\% e $40 \%$ das plantas com sintomas idênticos ao descrito anteriormente, sendo que na testemunha verificaram-se $40 \%$ das plantas com esses sintomas.

Tabela 8. Reação de plantas de melancia 'Crimson Sweet' premunizadas com as estirpes fracas (PRSV-W-1, PRSV-W-2 e PRSV-W-3) e duplamente desafiadas com a estirpe severa do vírus (PRSV-W-C) em campo.

\begin{tabular}{lcccc}
\hline Tratamento & \multicolumn{2}{c}{$\begin{array}{l}\text { Número de plantas testadas / número de } \\
\text { plantas com notas de sintomas } \geq 3^{*}\end{array}$} \\
\cline { 2 - 5 } & $10 / 10^{*}$ & $30 / 10$ & $13 / 11$ & $20 / 11$ \\
\hline PRSV-W-1 + PRSV-W-C & $13 / 0$ & $13 / 0$ & $13 / 1$ & $13 / 4$ \\
PRSV-W-2 + PRSV-W-C & $14 / 0$ & $14 / 2$ & $14 / 3$ & $14 / 5$ \\
PRSV-W-3 + PRSV-W-C & $10 / 0$ & $10 / 0$ & $10 / 1$ & $10 / 4$ \\
Não premunizada & $15 / 2$ & $15 / 3$ & $15 / 4$ & $15 / 6$ \\
\hline
\end{tabular}

* Datas da realização de leituras de sintomas.

$\mathrm{Na}$ avaliação da contaminação com outros vírus, feita no final do experimento, cujo resultado é apresentado na Tabela 9, estão incluídas somente as plantas sabidamente premunizadas e todas as plantas não premunizadas. De acordo com essa avaliação, notou-se que apenas cinco plantas premunizadas, reagiram positivamente apenas com o antissoro contra 0 
PRSV-W. As demais plantas premunizadas do campo foram infectadas com o ZYMV, ou com o ZLCV ou, ainda, com estes dois vírus concomitantemente. Além disso, por tratarem-se de plantas premunizadas, todas tiveram reação positiva com o antissoro contra o PRSV-W. Entre as plantas não premunizadas, uma reagiu apenas com o antissoro contra o PRSV-W. Das 14 restantes, apenas uma planta não foi infectada com algum desses vírus. Do total de plantas não premunizadas, $20 \%$ apresentavam infecção dupla de PRSV-W e ZYMV, 13,3\% de PRSV-W e ZLCV e 53,3\% infecção tripla. Portanto, 14 plantas não premunizadas $(93,3 \%)$ estavam infectadas com o PRSV-W no final do experimento. De modo geral, notou-se alta incidência do ZYMV $(78,8 \%)$, seguido pelo ZLCV (63,5\%), sendo que os dois vírus estavam presentes, na forma de infecção dupla, em $55,8 \%$ das plantas do experimento. Devido ao fato da maioria das plantas estarem infectadas com esses dois vírus, a avaliação do teste de recuperação foi comprometida. No caso das plantas premunizadas, não foi possível confirmar a infecção apenas com as estirpes fracas inicialmente inoculadas. Nas plantas inicialmente sadias, não foi possível identificar se a estirpe do PRSV-W detectada no teste serológico era fraca ou severa.

Tabela 9. Ocorrência de infecção simples com o PRSV-W, ZLCV e ZYMV e infecções duplas e triplas com esses vírus em plantas de melancia 'Crimson Sweet' premunizadas com três estirpes fracas do PRSV-W e não premunizadas.

\begin{tabular}{lccccc}
\hline Tratamento & $\begin{array}{c}\text { № } \\
\text { Plantas }\end{array}$ & PRSV-W & $\begin{array}{c}\text { PRSV-W } \\
+ \text { ZYMV }\end{array}$ & $\begin{array}{c}\text { PRSV-W } \\
+ \text { ZLCV }\end{array}$ & $\begin{array}{c}\text { PRSV-W + } \\
\text { ZYMV + ZLCV }\end{array}$ \\
\hline PRSV-W-1 & 13 & 1 & 6 & 0 & 6 \\
PRSV-W-2 & 14 & 3 & 2 & 1 & 8 \\
PRSV-W-3 & 10 & 1 & 1 & 1 & 7 \\
Não premunizadas & 15 & 1 & 3 & 2 & 8 \\
\hline Total & 52 & 6 & 12 & 4 & 29 \\
\hline
\end{tabular}


Todas as plantas premunizadas e não premunizadas com notas de sintomas iguais ou maiores do que três no início da colheita, dia 13 de novembro, foram desconsideradas na avaliação da produção. Os resultados de produção e quantidade de açúcares (grau brix) dos frutos colhidos das plantas premunizadas e não premunizadas, expostas à infecção natural, estão apresentados na Tabela 10. Os resultados mostraram que a produção média das plantas premunizadas com as estirpes fracas não diferiu significativamente, ao nível de $5 \%$, das plantas não premunizadas. A produção das plantas premunizadas com as estirpes fracas PRSV-W-1 e PRSV-W-3 apresentou uma redução de 14,6\% e 13,8\%, respectivamente, quando comparada com a produção das plantas não premunizadas. A produção das plantas premunizadas com a estirpe fraca PRSV-W-2 apresentou um incremento de $6,7 \%$, na mesma comparação. De modo geral, a produção das plantas premunizadas foi $7,2 \%$ menor do que a das plantas não premunizadas. $O$ número médio de frutos e o peso médio dos mesmos, por conseguinte, também não diferiram significativamente entre os tratamentos. A avaliação da polpa dos frutos, feita com o auxílio de um refratômetro, mostrou que não houve diferença significativa do grau brix dos frutos das plantas premunizadas em relação ao daquelas não premunizadas. Também não foram verificados defeitos visuais na polpa dos frutos das plantas premunizadas. 
Tabela 10. Produção e grau brix das plantas de melancia premunizadas com as estirpes fracas PRSV-W-1, PRSV-W-2 e PRSV-W-3 e sadias expostas àinfecção natural.

\begin{tabular}{lccccc}
\hline Tratamento & $\begin{array}{c}\text { Número de } \\
\text { plantas }\end{array}$ & $\begin{array}{c}\text { № médio de } \\
\text { frutos/planta }\end{array}$ & $\begin{array}{c}\text { Peso médio } \\
\text { dos frutos } \\
(\mathrm{kg})\end{array}$ & $\begin{array}{c}\text { Produção } \\
\text { média/planta } \\
(\mathrm{kg})\end{array}$ & $\begin{array}{c}\text { Grau } \\
\text { brix }\end{array}$ \\
\hline PRSV-W-1 & 12 & $2,0 \mathrm{a}^{*}$ & $10,2 \mathrm{a}$ & $20,4 \mathrm{a}$ & $11,2 \mathrm{a}$ \\
PRSV-W-2 & 11 & $2,5 \mathrm{a}$ & $10,4 \mathrm{a}$ & $25,5 \mathrm{a}$ & $11,3 \mathrm{a}$ \\
PRSV-W-3 & 9 & $2,1 \mathrm{a}$ & $9,8 \mathrm{a}$ & $20,6 \mathrm{a}$ & $12,0 \mathrm{a}$ \\
Não premunizadas & 11 & $2,5 \mathrm{a}$ & $9,4 \mathrm{a}$ & $23,9 \mathrm{a}$ & $11,3 \mathrm{a}$ \\
\hline
\end{tabular}

* Números acompanhados da mesma letra não diferem significativamente ao nível de 5\% de significância. 


\section{DISCUSSÃO}

De acordo com a proposta do trabalho, inicialmente foi selecionada uma estirpe fraca a partir de bolhas de folhas de plantas de melancia com mosaico, denominada PRSV-W-3. A obtenção de estirpes fracas através desse método já havia sido realizada com sucesso por Rezende (1985), para o vírus do mosaico do mamoeiro (Papaya ringspot virus - type P), em bolhas de folhas desta frutífera naturalmente infectada em campo. Anos mais tarde, Rezende et al. (1994) também obtiveram duas estirpes fracas do PRSV-W (PRSV-W-1 e PRSV-W-2) a partir de bolhas de folhas de abobrinha de moita infectadas com estirpes severas deste vírus. Recentemente, Novaes (2002) obteve seis estirpes fracas do Passion fruit woodiness virus (PWV), que causa 0 endurecimento dos frutos do maracujazeiro, sendo três a partir de plantas de elite encontradas em plantios afetados pela doença, e três de bolhas de folhas de maracujazeiro com mosaico.

Embora não tenha sido objetivo deste trabalho avaliar a estabilidade da estirpe fraca PRSV-W-3, a sua constante transferência de plantas de abobrinha de moita e melancia para novas plantas destas espécies, desde que foi obtida, permite afirmar que se trata de uma estirpe estável. Em nenhuma planta infectada com essa estirpe foi observada intensificação de sintomas ao longo deste período de transferências (26 meses), embora tenha sido notado que os sintomas em abobrinha de moita foram ligeiramente mais acentuados do que os causados pelas estirpes fracas PRSV-W-1 e PRSV-W-2. No entanto, em plantas de melancia, os sintomas foram imperceptíveis para as três estirpes fracas. Rezende \& Pacheco (1997) estudando a estabilidade das estirpes PRSV-W-1 e PRSV-W-2, constataram que a primeira induziu sintomas fracos 
durante 28 meses de observações, após 18 transferências sucessivas para abobrinha de moita 'Caserta', enquanto a estirpe fraca PRSV-W-2 permaneceu estável por 22 meses. Depois deste período, as plantas infectadas com esta última estirpe tiveram os sintomas intensificados, semelhantes aos causados por estirpes severas do vírus. No entanto, após a recuperação da estirpe PRSV-W-2 de tecido desidratado, armazenado a $-20{ }^{\circ} \mathrm{C}$, nenhum outro caso de intensificação de sintomas foi notado durante as sucessivas transferências desta estirpe até os dias atuais (J.A.M. Rezende, informação pessoal). O caso mais evidente de estabilidade parece ser o das estirpes fracas do CTV, visto que em 30 anos de utilização na premunização de plantas cítricas, nenhuma menção à intensificação de sintomas foi relatada pelos autores (Cos ta \& Müller, 1980; Müller, 1972 e Müller \& Carvalho, 2001).

Nas avaliações preliminares para determinar as concentrações dos inóculos para os testes de infectividade das estirpes fracas, as inoculações foram feitas de acordo com o procedimento tradicional, utilizando o dedo indicador umedecido no inóculo, friccionando-o sem muita pressão sobre as folhas contendo abrasivo, a fim de não causar danos excessivos nos cotilédones. Os resultados desses testes mostraram que houve uma tendência de aumento da infectividade das estirpes fracas com 0 aumento da concentração do inóculo. Mesmo assim, verificou-se que a infectividade foi bastante variável, tanto entre as estirpes fracas, como entre as concentrações dos inóculos. Após a padronização das concentrações dos inóculos, os testes definitivos foram realizados de maneira semelhante aos anteriores, porém as inoculações foram feitas com o auxílio do pistilo de maceração umedecido no inóculo e friccionado sobre a folha com abrasivo. Este, com o próprio peso, já promove uma fricção mais acentuada do que o dedo indicador, a ponto de causar algum dano físico no tecido foliar. Nesses testes, a infectividade média das estirpes fracas foi superior a dos testes preliminares, atingindo $100 \% \mathrm{em}$ vários casos. Verificou-se ainda que a taxa de infectividade foi mais estável e representativa, não apresentando oscilações tanto em relação à concentração 
do inóculo quanto à estirpe fraca do vírus. Testes posteriores, para avaliar o efeito da pressão de fricção na infectividade das estirpes fracas do PRSV-W, realizados com a aplicação de maior pressão na fricç̧ão com o dedo indicador, resultaram em altas taxas de infectividade, independente da origem e da concentração do inóculo. Em vários casos a infectividade foi de 100\%.

As outras duas variáveis analisadas, espécie fonte do inóculo das estirpes fracas (abobrinha de moita vs melancia) e idade da planta-teste de melancia no momento da inoculação, também não parecem ter afetado a taxa de infectividade das estirpes fracas do PRSV-W. A ausência de interferência da espécie doadora do inóculo na infectividade já era esperada, pois seria pouco provável que extratos de abobrinha de moita atuassem como inibidores de infecção em plantas de melancia, de maneira semelhante ao que ocorre com extratos de Phytolacca $\mathrm{sp}$ e outras espécies vegetais relatadas na literatura (Gibbs \& Harrison, 1976).

Esses resultados corroboram aqueles obtidos por Dias e Rezende (2001) que apontaram dificuldades de infecção de plantas de melancia dos cultivares Charleston Gray, Crimson Sweet e Crimson Tide com as estirpes fracas PRSVW-1 e PRSV-W-2. Além disso, mostraram que a estirpe fraca originária de bolhas de folhas de melancia com mosaico (PRSV-W-3) teve a mesma taxa de infectividade das duas primeiras, obtidas de bolhas de folhas de abobrinha de moita com mosaico, não confirmando, portanto, a hipótese formulada por aqueles autores de que a menor infectividade das estirpes fracas PRSV-W-1 e PRSV-W-2 em melancia poderia estar associada com a origem e especificidade da estirpe fraca do vírus. $\mathrm{Na}$ verdade, os resultados indicaram que a menor taxa de infectividade das estirpes fracas do PRSV-W em plantas de melancia parece ser uma característica intrínseca dessas estirpes em relação a esta espécie de cucurbitácea, visto que a estirpe severa PRSV-W-C infectou $100 \%$ das plantas em qualquer situação. Mostraram ainda que o aumento da infectividade das 
estirpes fracas parece estar diretamente associado com a severidade do processo de inoculação mecânica.

Trabalhos anteriores de premunização de plantas de abobrinha de moita 'Caserta', de abóbora rasteira 'Menina Brasileira' e de abóbora híbrida do tipo Tetsukabuto, com as estirpes fracas PRSV-W-1 e PRSV-W-2, nunca fizeram menção de dificuldades de infecção das plantas dessas espécies (Dias \& Rezende, 2000; Rezende et al., 1994; Rezende, 1996 e Rezende et al., 1999). Em todos esses trabalhos, as plantas foram inoculadas mecanicamente com 0 dedo indicador, da maneira convencional e sempre se obteve $100 \%$ de plantas infectadas com apenas uma inoculação. Acrescente-se que no decorrer do presente trabalho, nas sucessivas transmissões mecânicas para a manutenção das fontes de inóculos das estirpes fracas PRSV-W-1, PRSV-W-2 e PRSV-W3 , em plantas de abobrinha de moita e de melancia, sempre se alcançaram $100 \%$ de plantas infectadas da primeira espécie, sem qualquer dificuldade. No entanto, nas inoculações das plantas de melancia, freqüentemente constatavam-se falhas na infecção de algumas plantas. Deve-se mencionar também que não há relatos de problemas de infectividade das estirpes fracas do ZYMV, CMV e WMV-2 utilizadas em trabalhos de premunização de cucurbitáceas em outros países (Cho et al., 1992; Kosaka \& Fukunishi, 1997; Lecoq et al.,1991; Montasser et al., 1991 e 1998; Perring et al., 1995; Walkey et al., 1992; Wang et al., 1991 e Yarden et al., 2000).

Em trabalho recente, Della Vecchia (2001), comparando as estirpes fracas e severas do PRSV-W com base na seqüência de nucleotídeos do gene da capa protéica, demonstrou que as estirpes fracas PRSV-W-1 e PRSV-W-2 apresentam $100 \%$ de homologia; enquanto que, quando comparadas com a estirpe fraca PRSV-W-3, a homologia foi de 98\%. Comparando as estirpes fracas PRSV-W-1 e PRSV-W-2 com a estirpe severa PRSV-W-C, obteve-se 95\% de homologia; enquanto que a PRSV-W-3, nesse caso, apresentou 93\% de homologia. Embora as estirpes fracas mostrem certa diferença da estirpe severa, não há elementos para supor que esta esteja associada com a variação 
na infectividade. Além disso, o gene da capa protéica representa pouco menos de $10 \%$ do genoma desse potyvirus.

Avaliando o efeito protetor da estirpe fraca PRSV-W-3 em casa de vegetação, verificou-se que ela protegeu as plantas de melancia. Não foi verificada a presença de sintomas severos em nenhuma planta premunizada e desafiada, mas apenas no controle inicialmente sadio. A proteção foi confirmada pela ausência de recuperação da estirpe severa utilizada na inoculação das plantas premunizadas de melancia, para plantas de abobrinha de moita. O efeito protetor das estirpes fracas PRSV-W-1 e PRSV-W-2 em plantas de melancia já havia sido verificado por Dias \& Rezende (2001). O efeito protetor dessas duas estirpes fracas também foi relatado em outras espécies de cucurbitáceas: abobrinha de moita 'Caserta' (Rezende et al., 1994 e Rezende, 1996); abóbora rasteira 'Menina Brasileira' (Rezende et al., 1999) e abóbora híbrida do tipo Tetsukabuto (Dias \& Rezende, 2000).

Com relação à proteção da estirpe fraca PRSV -W-3, comparada com as duas estirpes fracas obtidas de abobrinha de moita, em um experimento em campo, verificou-se que as plantas premunizadas não apresentaram sintomas severos de mosaico até o momento em que foram constatadas as primeiras contaminações com outros vírus, em especial o ZLCV e o ZYMV. Com base no teste de PTA-ELISA realizado com amostras coletadas no final do experimento e na recuperação do(s) vírus presente(s) nessas plantas, para plantas-teste de abobrinha de moita, confirmou-se que o ZYMV foi o principal contaminante (78,8\%), seguido pelo ZLCV $63,5 \%)$. Esses dados, apesar de não estarem relacionados com os objetivos deste trabalho, chamam a atenção se comparados com os valores relatados por Yuki et al. (2000) sobre a incidência de viroses de cucurbitáceas no Estado de São Paulo. Naquela ocasião, constataram-se incidências de ZYMV e de ZLCV da ordem de $25 \%$ e $8 \%$, respectivamente. A ocorrência desses vírus inviabilizou o teste de recuperação, utilizado como forma de confirmar a proteção das estirpes fracas, já que o ZYMV causa sintomas similares aos das estirpes severas do PRSV-W em 
abobrinha de moita.

Mesmo com a alta incidência de outras espécies de vírus que contaminaram as plantas do campo experimental, quase no final das avaliações, os resultados de produção das plantas premunizadas e não premunizadas foram bastante satisfatórios. As plantas premunizadas com as estirpes fracas PRSV-W-1 e PRSV-W-3 tiveram reduções de 14,6\% e 13,8\%, respectivamente, na produção de frutos comerciais, em relação à produção das plantas não premunizadas. Por outro lado, a produção das plantas premunizadas com a estirpe fraca PRSV-W-2 foi sensivelmente maior, da ordem de $6,7 \%$, do que a das plantas não premunizadas. Estes resultados diferem daqueles obtidos por Dias \& Rezende (2001), onde a premunização com as estirpes PRSV-W-1 e PRSV-W-2 acarretou uma redução na produção de 10,8 a 50\% em relação æ̀s plantas inicialmente sadias. Uma hipótese para explicar a produção satisfatória das plantas premunizadas no presente experimento seria a melhoria das condições do solo com a adição de adubo orgânico, o que teria proporcionado um efeito compensatório sobre a premunização. Esta sugestão baseia-se no fato de que os experimentos de Dias \& Rezende (2001) foram conduzidos na mesma propriedade onde foi realizado o presente teste, porém o produtor não realizava adubação orgânica regularmente. A confirmação dessa sugestão só será possível com a realização de experimentos que comparem o desenvolvimento e a produção de plantas premunizadas de melancia, crescendo em uma mesma área com e sem adubação orgânica.

Com relação à qualidade da polpa, verificou -se que não houve alteração no conteúdo de açúcares do suco. A qualidade visual externa e interna dos frutos também não parece ter sido afetada, pois não foi verificada qualquer deformação nos frutos analisados. Este fato já era esperado, visto que nas várias espécies em que essas estirpes foram testadas, não houve relato de dano nos frutos associados com a premunização. Ao invés disso, houve melhora estética nos frutos, como verificado naqueles colhidos de abóbora 
híbrida do tipo Tetsukabuto (Dias \& Rezende, 2000), os quais são normalmente comercializados com sintomas de deformações causadas por infecções virais.

Os resultados deste trabalho, juntamente com aqueles de Dias e Rezende (2001), permitem sugerir que as três estirpes fracas do PRSV-W podem ser utilizadas para o controle do mosaico comum em melancia, da mesma forma como já foram preconizadas para outras espécies de cucurbitáceas (Rezende et al., 1994; Rezende et al., 1999; Dias \& Rezende, 2000), com algumas recomendações adicionais. A correta fertilização das covas deve ser sempre aconselhada, para que o desenvolvimento adequado das plantas compense qualquer efeito deletério das estirpes fracas sobre a produção de frutos. Para compensar a baixa infectividade das estirpes fracas em melancia, pode-se recomendar o plantio de outras espécies de cucurbitáceas, mais facilmente infectadas com as estirpes fracas, ao redor ou até no interior da área de plantio da melancia, para servirem de fontes de inóculos das estirpes premunizantes. Essas poderão ser transmitidas para as plantas de melancia, que não foram infectadas por ocasião da inoculação massal das mudas, através da ação dos afídeos. A ocorrência de infecção natural de plantas com estirpes fracas do PRSV-W já foi constatada em campos de produção de abóbora 'Takayama' (Tetsukabuto), em que as mudas foram premunizadas com inóculo aplicado com uma pistola para pintura sob pressão de $7,0 \mathrm{kgf} \mathrm{cm}^{-2}$. A eficiência da inoculação nesse caso variou de $63 \%$ a $79 \%$. No entanto, avaliações feitas no final do ciclo da cultura, indicaram que a maioria das plantas que estavam sadias por ocasião do transplante, foram naturalmente infectadas com a estirpe fraca, através da ação dos afídeos vetores, tornando-as premunizadas (Dias \& Rezende, 2000). O plantio de outra espécie de cucurbitácea premunizada, além de funcionar como fonte de inóculo das estirpes fracas, poderá gerar uma receita adicional para o produtor com a colheita e a comercialização dos frutos. 


\section{CONCLUSÃO}

A origem da estirpe fraca, a concentração e a fonte doadora do inóculo e a idade das plantas de melancia no momento da inoculação não afetaram a infectividade das estirpes fracas do PRSV-W em mudas dessa espécie. 


\section{REFERÊNCIAS BIBLIOGRÁFICAS}

ADLERZ, W. C. Spring aphid flights and incidence of watermelon mosaic virus 1 and 2 in Florida. Phytopathology, v.64, n.3, p.350-353, 1974.

ALBUQUERQUE, F.C.; IKEDA, H.; COSTA A.S. Ocorrência do vírus do mosaico da melancia (Citrullus vulgaris Schrad.) em plantações de melão (Cucumis melo L.) na região de Belém-PA. Revista de Olericultura, v.12, p.94, 1972. /resumo/

APSNET. Genetic engineering: A novel and powerful tool to combat plant virus diseases. http://www.apsnet.org/online/feature/biotechnology/ engineering.html. (19 nov. 2002)

ÁVILA, A.C.; DELLA VECCHIA, P.T.; LIN, M.T.; d'OLIVEIRA, L.O.; ARAUJO, J.P. de. Identificação do vírus do mosaico da melancia em melão (Cucumis melo) e melancia (Citrullus lanatus) na região do Submédio São Francisco. Fitopatologia Brasileira, v.9, n.1, p.113-117, 1984.

AZEVEDO, S.M. Herança da resistência ao vírus da mancha anelar do mamoeiro - estirpe melancia (PRSV-W) em melancia [Citrullus lanatus (Thunb.) Matsumara \& Nakai]. Lavras, 2001. 53 p. Tese (Doutorado) Universidade Federal de Lavras. 
AZEVEDO, S.M.; MALUF, W.R.; OLIVEIRA, A.C.B.; FREITAS, J.A.; SILVEIRA, M.A.; GOMES, L.A.A.; MORETTO, P. Triagem de cultivares, híbridos e introduções de melancia quanto àreação de resistênci a ao vírus da mancha anular do mamoeiro - estirpe melancia (PRSV-W). In: CONGRESSO BRASILEIRO DE OLERICULTURA, 38; Petrolina, 1998. Resumos. Petrolina: SOB, 1998. p.27.

CAMARGO FILHO, W.P.; MAZZEI, A.R. O mercado de melancia no Mercosul. Informações Econômicas, v.32, n.2, p.61-64, 2002.

CASTELLANE, P.D.; CORTEZ, G.E.P. A cultura da melancia. Jaboticabal: FUNEP, 1995. $64 \mathrm{p}$.

CHABARIBERY, D.; ALVES, H.S. Produção e comercialização de limão, mamão, maracujá e melancia em São Paulo. Informações Econômicas, v.31, n.8, p.43-51, 2001.

CHAGAS, C. M. Mosaico da abóbora em pepino. O Biológico, v. 36, p. 326, 1970.

CHALFANT, R.B., JAWORSKI, C.A., JOHNSON, A.W., SUMMER, D.R. Reflective film mulches, millet barriers, and pesticides effects on watermelon mosaic virus, insects, nematodes, soil borne fungi, and yield of yellow summer squash. Journal of the American Society for Horticultural Science, v.102, p.11-15, 1977.

CHANNON, A.G.; CHEFFINS, N.J.; HITCHON, G.M.; BARKER, J. The effect of inoculation with an attenuated mutant strain of tobacco mosaic virus on the growth and yield of early glasshouse tomato crop. Annals of Applied Biology, v.88, n.1, p.121-129, 1978. 
CHO, J.J.; ULLMAN, D.E.; WHEATLEY, E.; HOLLY J.; GONSALVES, D. Commercialization of ZYMV cross protection for zucchini production in Hawaii. Phytopathology, v.82, n.10, p.1073, 1992. /abstract/

COSTA, C.L. Variações sazonais da migração de Myzus persicae em Campinas nos anos de 1967 a 1969. Bragantia, v.29, n.32, p.347-359, 1970.

COSTA, C. L.; COSTA, A. S. Redução na disseminação de mosaico em abóbora de moita (Cucurbita pepo var. melopepo) com superfícies repelentes aos afídeos vetores. Revista de Olericultura, v.11, p.24-25, 1971.

COSTA, A.S.; KITAJIMA, E.W.; NAGAI, H. Alguns vírus que afetam o pepino (Cucumis sativus L.) em São Paulo. Revista de Olericultura, v.12, p.100101, 1972. /resumo/

COSTA, C. L.; MÜLLER, G. W. Tristeza control by cross protection: a U.S.Brazil cooperative success. Plant Disease, v. 64, n. 6, p. 538-541, 1980.

CRUZ, E.S.; PAZ, C.D.; PIO-RIBEIRO, G.; BATISTA, D.C.; PEREIRA FILHO, G.G.; ANDRADE, G.P. Levantamento de viroses em melancia e melão no submédio São Francisco. Summa Phytopatologica, v.25, n.1, p. 21, 1999. /resumo/

CUPERTINO, F.P.; KITAJIMA, E.W.; FONSECA, M.E.N.; MEYER, M.C. Viroses em plantas olerícolas no Estado de Goiás. Fitopatologia Brasileira, v.13, n.2, p.101, 1988. /Resumo/ 
DELLA VECCHIA, M.G. Comparação de estirpes fracas e severas do Papaya ringspot virus com base na capa protéica. Piracicaba, 2001. 46 p. Dissertação (Mestrado) - Escola Superior de Agricultura "Luiz de Queiroz", Universidade de São Paulo.

DIAS, P.R.P.; REZENDE, J.A.M. Premunização da abóbora híbrida Tetsukabuto para o controle do mosaico causado pelo Papaya ringspot virus - type W. Summa Phytopathologica, v.26, n.4, p.390-398, 2000.

DIAS, P.R.P.; REZENDE, J.A.M. Problemas na premunização de melancia para o controle do mosaico causado pelo Papaya ringspot virus. Fitopatologia Brasileira, v.26, n.3, p.651-654, 2001.

DODDS, J.A. Cross-protection and interference between eletrophoretically distinct strains of cucumber mosaic virus in tomato. Virology, v.118, p.235240, 1982.

FLETCHER, J.T. The use of avirulent strains to protect plants against the effects of virulent strains. Annals of Applied Biology, v.89, n.1, p.110-114, 1978.

FNP CONSULTORIA \& COMÉRCIO. Agrianual 2002: Anuário da Agricultura Brasileira. São Paulo, 2002. 536p.

FOOD AND AGRICULTURE ORGANIZATION - FAO. Faostat Agriculture Data. http://apps.fao.org. (07 Nov. 2002)

FUCHS, M.; TRICOLI, D.M.; CARNEY, K.J.; SCHESSER, M.; McFERSON, J.R.; GONSALVES, D. Comparative virus resistance and fruit yield of transgenic squash with single and multiple coat protein genes. Plant Disease, v.82, n.12, p.1350-1356, 1998. 
GALLITELLI, D.; MARTELLI, G.; MONTASSER, M.S.; TOUSIGNANT, M.E.; KAPER, J.M. Satellite-mediated protection of tomato against cucumber mosaic virus: II. Field test under natural epidemic conditions in Southern Italy Plant Disease, v.75, n.1, p.93-95, 1991.

GALLO, D.; NAKANO, O.; SILVEIRA NETO, S.; CARVALHO, R.P.L.; BATISTA, G.C.; BERTI FILHO, E.; PARRA, J.R.P.; ZUCCHI, R.A.; ALVES, S.B.; VENDRAMIM, J.D. Manual de Entomologia Agrícola. 2.ed São Paulo: Ed. Agronômica Ceres, 1988. 649p.

GIAMPAN, J.S.; REZENDE, J.A.M. Transmissibilidade por afídeos e reação de diversas espécies vegetais à estirpes fracas premunizantes do PRSV -W. Summa Phytopathologica, v.27, n.3, p.279-283, 2001.

GIBBS, A.; HARRISON, B. Plant virology: the principles. London: Edward Arnold, 1976. 292p.

GOTO, T.; IIZUKA, N.; KOMOCHI, S. Selection and utilization of an attenuated isolate of pepper strain of tobacco mosaic virus. Annals of the Phytopathological Society of Japan, v.50, p.221-228, 1984.

GOURGOPAL ROY; JAIN, R.K.; BHAT, A.I.; VARMA, A. Comparative host range and serological studies of papaya ringspot potyvirus isolates. Indian Phytopathology, v.52, n.1, p.14-17, 1999.

HOJO, H,; SILVA, N. de; PAVAN, M.A. Triagem de cultivares e híbridos de melancia para resistência ao vírus do mosaico do mamoeiro - estirpe melancia (VMM-Me). Summa Phytopathologica, v.17, n.2, p.113-118, 1991. 
INSTITUTO DE ECONOMIA AGRÍCOLA - IEA. Prognóstico Agrícola 1998/99. São Paulo: Instituto de Economia Agrícola, 1998. 2v.

JIMENEZ DIAZ, F. Maleza hospedera de virus, fluctuacion problacional de vectores y su relacion com enfermedades virales del melon (Cucumis melo L.) en la Comarca Lagunera, Mexico. Revista Mexicana de Fitopatologia, v.14, n.1, p.31-37, 1996.

KITAJIMA, E.W.; COSTA, A.S. Alterações no complexo de Golgi associada a infecção de tecido foliar de plantas infectadas por uma estirpe do vírus do vira-cabeça. Revista da Sociedade Brasileira de Fitopatologia, v.5, p.180-181, 1972. /resumo/

KTAJIMA, E.W., SÁ, P.B.; DE, RITZINGER, C.H.S.P.; RODRIGUES, M.G.R. Detecção de partículas do tipo rhabdovirus em algumas compostas, aboboreira e mamoeiro. Fitopatologia Brasileira, v.16, n.1, p.141-144, 1991.

KOSAKA, Y; FUKUNISHI, T. Attenuated isolates of soybean mosaic virus derived at a low temperature. Plant Disease, v.77, n.9, p.882-886, 1993.

KOSAKA, Y.; FUKUNISHI, T. Application of cross-protection to the control of black soybean mosaic disease. Plant Disease, v.78, n.4, p.339-341, 1994.

KOSAKA, Y.; FUKUNISHI, T. Multiple inoculation with three attenuated viruses for the control of cucumber virus disease. Plant Disease, v.81, n.7, p.733738, 1997.

KUNKEL, L.O. Studies on acquired immunity with tobacco and aucuba mosaics. Phytopathology, v.24, n.5, p.437-466, 1934. 
KUTI, J.O.; MOLINE, H.E. Effects of inoculation with a mild strain of tomato aspermy virus on the growth and yield of tomatoes and the potential for cross-protection. Journal of Phytopathology, v.115, n.1, p.56-60, 1986.

LATORRE, B.A.; FLORES, V. Strain identification and cross protection of potato virus $Y$ affecting tobacco in Chile. Plant Disease, v.69, p.930-932, 1985.

LECOQ, H., LEMAIRE, J.M.; WIPF-SCHEIBEL, C. Control of zucchini yellow mosaic virus in squash by cross protection. Plant Disease, v.75, n.2, p.208211, 1991.

LIMA, J.A.A, FERNANDES, E.R.; MENDES, M.L. Identificação sorológica de "Watermelon mosaic virus 1" em cucurbitáceas cultivadas e nativas do Rio Grande do Norte. Fitopatologia Brasileira, v.5, n.3, p.414, 1980. /resumo/.

LIMA, J.A.A.; VIEIRA, A.C. Distribuição do vírus do mosaico da abóbora em municípios cearenses e gama de hospedeiros de um isolado. Fitopatologia Brasileira, v.17, n.1, p.112-114, 1992.

LIMA, M.F.; BARBOSA, L.F.; ÁVILA, A.C. de. Levantamento de viroses na cultura da melancia na região do Submédio São Francisco. Fitopatologia Brasileira, v.22, p.337, 1997. Suplemento.

LIMA, M.F.; QUEIROZ, M.A. de; DIAS, R. de C.S. Avaliação de germoplasma de melancia a viroses no Submédio do vale São Francisco. Horticultura Brasileira, v.17, p.20-22, 1999. Suplemento. 
LIN, M.T.; KITAJIMA, E.W.; MUNHOZ, J.O. Isolamento e propriedade do vírus da necrose da abóbora, um possível membro do grupo "Tobacco Necrosis Virus". Fitopatologia Brasileira, v.8, n.3, p.622, 1983.

LOVISOLO, O. Virus and viroid diseases of cucurbits. Acta Horticulturae, n.88, p.33-82, 1980.

MAHMOOD, T.; RUSH, C.M. Evidence of cross protection between beet soilborne mosaic virus and beet necrotic yellow vein virus in sugar beet. Plant Disease, v.83, n.6, p.521-526, 1999.

MONTASSER, M.S.; TOUSIGNANT, M.E.; KAPER, J.M. Satellite-mediated protection of tomato against cucumber mosaic virus: I. Greenhouse experiments and simulated epidemic conditions in the field. Plant Disease, v.75, n.1, p.86-92, 1991.

MONTASSER, M.S.; TOUSIGNANT, M.E.; KAPER, J.M. Viral satellite RNAs for the prevention of cucumber mosaic virus (CMV) disease in field-grown pepper and melon plants. Plant Disease, v.82, n.12, p.1298-1303, 1998.

MOORE, W. D.; SMITH, F. F.; JOHNSON, G. V.; WOLDENBARGER, W. O. Reduction of aphid population and delayed incidence of virus infection on yellow neck squash by use of aluminum foil. Proceedings of the Florida State Horticultural Society, v.78, p.187-191, 1965.

MOURA, M.C.C.L.; LIMA, J.A.A.; OLIVEIRA, V.B.; GONÇALVES, M.F.B. Identificação sorológica de espécies de vírus que infectam cucurbitáceas em áreas produtoras do Maranhão. Fitopatologia Brasileira, v.26, n.1, p.90-92, 2001. 
MOWAT, W.P.; DAWSON, S. Detection of plant viruses by ELISA using crude sap extracts and unfractionated antisera. Journal of Virological Methods, v.15, p.233-247, 1987.

MÜLLER, G.W. Estudos sobre a interação entre isolados do vírus da tristeza dos citros, e controle da moléstia em limão Galego por premunização. Piracicaba, 1972. 68p. Tese (Doutorado) - Escola Superior de Agricultura "Luiz de Queiroz", Universidade de São Paulo.

MÜLLER, G.W.; CARVALHO, S.A. Trinta e três anos de controle da tristeza dos citros por premunização no Estado de São Paulo. Fitopatologia Brasileira, v.26, p.241, 2001. Suplemento.

MÜLLER, G.W.; COSTA, A.S. Further evidence on protective interference in citrus tristeza. In: CONFERENCE OF THE INTERNATIONAL ORGANIZATION OF CITRUS VIROLOGISTS, 4; Italy, 1966. Proceedings. Rome: s.ed., 1968. p.71-82.

MÜLLER , G.W.; COSTA, A.S. Tristeza control in Brazil by preimmunization with mild strains. Proceedings of the International Society Citricultura, v.3, p.868-872, 1977.

NOVAES, Q.S. Seleção de estirpes fracas do Passion fruit woodiness vírus e tentativas de premunização para o controle do endurecimento dos frutos do maracujazeiro. Piracicaba, 2002. 74p. Tese (Doutorado) - Escola Superior de Agricultura "Luiz de Queiroz", Universidade de São Paulo.

OLIVEIRA, V.B.; LIMA, J.A.A.; VALE, C.C.; PAIVA, W.O. Caracterização biológica e sorológica de isolados de potyvirus obtidos de cucurbitáceas no nordeste brasileiro. Fitopatologia Brasileira, v.25, n.4, p.628-636, 2000. 
PACHECO, D.A. Biomassa, estimativa da concentração viral e sintomatologia de cucurbitáceas infectadas com estirpes fracas e severa do Papaya ringspot virus. Piracicaba, 2002. 42p. Dissertação (Mestrado) - Escola Superior de Agricultura "Luiz de Queiroz", Universidade de São Paulo.

PARES, R.D.; MARTIN, A.B.; FITZELL, R.D. Virus-induced tip necrosis of passionfruit (Passiflora edulis Sims.). Australian Plant Pathology, v.14, p.76-78, 1985.

PAVAN, M.A. Vírus do mosaico da melancia: purificação, viabilidade e distribuição nas principais regiões produtoras de pepino e abobrinha de Minas Gerais. Viçosa, 1985. 69 p. Dissertação (Mestrado) - Universidade Federal de Viçosa.

PAVAN, M.A.; CARVALHO, M.G.; FERNANDES, J.J. Distribuição do vírus do mosaico da melancia (papaya ringspot virus - W), nas principais regiões produtoras de pepino (Cucumis sativus) e abobrinha (Cucurbita pepo) de Minas Gerais. Fitopatologia Brasileira, v.14, n.1, p.84-85, 1989.

PEASLEY, D.; FITZELL, R.D. Passionfruit industry benefits through scion wood scheme. Agriculture Gazette, v.92, p.5-8, 1981.

PERRING, T.M., FARRAR, C.A.; BLUA, M.J., WANG, H.L.; GONSALVES, D. Cross protection of cantaloupe with a mild strain of zucchini yellow mosaic virus: effectiveness and application. Crop Protection, v.14, n.7, p.601-606, 1995.

PERRING, T.M.; GRUENHAGEN, N.M.; FARRAR, C.A. Management of plant viral diseases through chemical control of insect vectors. Annual Review of Entomology, v.44, p.457-481, 1999. 
POSNETTE, A.F.; TODD, J.Mc.A. Virus diseases of cacao in West Africa. IX. Strain variant and interference in virus $1 \mathrm{~A}$. Annals of Applied Biology, v.43, n.3, p.433-453, 1955.

POZZER, L.; NAGATA, T.; LIMA, M.I.; KITAJIMA, E.W.; RESENDE, R. DE O.; DE ÁVILA, A.C. A new tospovirus infecting Cucurbitaceae in Brazil. Fitopatologia Brasileira, v.19, n. 1, p.21, 1994. /abstract/

PURCIFULL, D.; EDWARDSON, J.; HIEBERT, E.; GONSALVES, D. Papaya ringspot virus. CMI/AAB. Description of plant viruses, n.292, 1984. 8p.

RABELO, L.C. Seleção de estirpe fraca do Zucchini yellow mosaic vírus (ZYMV) e controle dos mosaicos comum (Papaya ringspot vírus) e amarelo (ZYMV) por dupla premunização em abobrinha-de-moita. Piracicaba, 2002. 55p. Dissertação (Mestrado) - Escola Superior de Agricultura "Luiz de Queiroz", Universidade de São Paulo.

RAMOS, N.F.; LIMA, J.A.A.; SANTOS, A.A.; GONÇALVES, M.F.B. Plantas de meloeiro com infecção mista de espécies de vírus em campos experimentais. Fitopatologia Brasileira, v.27, p.211, 2002. Suplemento.

RAST, A.T.B. MII-16, an artificial symptomless mutant of tobacco mosaic virus for seedling inoculation on tomato crops. Netherlands Journal of Plant Pathology, v.78, p.110-112, 1972.

RAST, A.T.B. Variability of tobacco mosaic virus in relation to control of tomato mosaic in glasshouse tomato crop by resistence breeding and cross protection. Agricultural Research Reporter, v.834, p.1-76, 1975. 
REZENDE, J.A.M. Tentativas de premunização para o controle do mosaico do mamoeiro. Piracicaba, 1985. 64p. Dissertação (Mestrado) - Escola Superior de Agricultura "Luiz de Queiroz", Universidade de São Paulo.

REZENDE, J.A.M. Premunização de duas espécies e um híbrido de Cucurbita para o controle do mosaico causado pelo vírus do mosaico do mamoeiro estirpe melancia. Piracicaba, 1996. 88p. Tese (Livre-Docência)- Escola Superior de Agricultura "Luiz de Queiroz", Universidade de São Paulo.

REZENDE, J.A.M.; GALLETI, S.R.; SCAGLIUSI, S.M.M.; POZZER, L.; RESENDE, R. DE. O.; ÁVILA, A.C. de. Incidência e algumas características biológicas e serológicas de um tospovirus em abobrinha de moita em São Paulo. Fitopatologia Brasileira, v.20, p.343-344, 1995. Suplemento.

REZENDE, J.A.M.; PACHECO, D.A. Estabilidade de isolados fracos premunizantes do vírus do mosaico do mamoeiro - estirpe melancia. Fitopatologia Brasileira, v.22, n.1, p.64-68, 1997.

REZENDE, J.A.M.; PACHECO, D.A. Control of papaya ringspot virus-type W in zucchini squash by cross protection in Brazil. Plant Disease, v.82, n.2, p.171-175, 1998.

REZENDE, J.A.M., PACHECO, D.A.; IEMMA, A.F. Efeitos da premunização da abóbora 'Menina Brasileira' com estirpes fracas do vírus do mosaico do mamoeiro-estirpe melancia. Pesquisa Agropecuária Brasileira, v.34, n.8, p.1481-1489, 1999.

REZENDE, J.A.M.; YUKI, V.A.; VEGA, J.; SCAGLIUSI, S.M.M.; BORBA, L.F.; COSTA, A.S. Isolados fracos do Potyvirus causador do mosaico da abobrinha presentes em bolhas atuam na premunização. Fitopatologia Brasileira, v.18, n.1, p.55-61, 1994. 
ROBINSON, R.W.; DECKER-WALTERS, D.S. Cucurbits. Wallingford: CAB International, 1997. 226p.

SÁ, P.B. de; KITAJIMA, E.W. Characterization of an isolate of watermelon mosaic virus 2 (WMV-2) from Brazil. Fitopatologia Brasileira, v.16, n.3, p.217-233, 1991.

SÁNCHEZ, M.V.; AGÜERO, R.; RIVERA, C. Plantas hospederas de los virus más importantes que infectan el melón, Cucumis melo (Cucurbitaceae) en Costa Rica. Revista de Biologia Tropical, v.46, n.1, p.13-25, 1998.

SAS INSTITUTE. SAS/STAT user's guide. 4.ed. Statistical Analyse System Institute, 1990.

SHEEN, T.F.; WANG, H.L.; WANG, D.N. Control of Papaya ringspot virus by cross protection and cultivation techniques. Journal of the Japan Society of Horticultural Science, v.67, p.1232-1235, 1998.

SHUKLA, D.D.; LAURICELLA, R.; WARD, C.W. Serology of potyviruses: current problems and some solutions. Archives of Virology, p.57-69, 1992. Supplement 5.

SIMMONDS, J.H. Mild strain protection as a means of reducing losses from the Queensland woodiness virus in the passion vine. Queensland Journal of Agricultural Science, v.16, n.4, p.371-380, 1959.

SITTOLIN, I.M. Tolerância de melancia aos vírus do mosaico amarelo da abobrinha-de-moita e do mosaico da melancia-2. Botucatu, 1998. 72p. Tese (Doutorado) - Faculdade de Ciências Agronômicas, Universidade Estadual de São Paulo. 
STANGARLIN, O.S.; DIAS, P.R.P.; BURIOLLA, J.E.; REZENDE, J.A.M. Incidência de viroses em ensaios de avaliações de genótipos de abóboras e de pepino na região de Dourados/MS. Fitopatologia Brasileira, v.26, p.532, 2001. Suplemento.

STANGARLIN, O.S.; DIAS, P.R.P.; REZENDE, J.A.M. Levantamento das viroses em cucurbitáceas no Estado do Mato Grosso do Sul, Brasil. Summa Phytopathologica, v.26, n.1, p.132, 2000.

STRANGE, E.B.; GUNER, N.; PESIC-VANESBROECK, Z.; WEHNER, T.C. Screening the watermelon germplasm collection for resistance to Papaya ringspot virus - type W. Crop Science, v.42, n.4, p.1324-1330, 2002.

TIEN, P.; ZHANG, X.; QIU, B.; WU, G. Satellite RNA for control of plant diseases caused by cucumber mosaic virus. Annals of Applied Biology, v.111, n.1, p.143-152, 1987.

TOMLINSON, J.A.; SHEPHERD, R.J. Studies on mutagenesis and crossprotection of cauliflower mosaic virus. Annals of Applied Biology, v.90, n.2, p.223-231, 1978.

VALKONEN, J.P.T.; RAJAMÄKI, M.L.; KEKARAINEN, T. Mappig of viral genomic regions important in cross-protection between strains of a Potyvirus. Molecular Plant-Microbe Interactions, v.15, n.7, p.683-692, 2002.

VAN REGENMORTEL, M.H.V. Watermelon mosaic virus. CMI/AAB. Description of Plant Viruses, n.63, 1971. 4p. 
VEGA, J.; REZENDE, J.A.M.; YUKI, V.A Detecção do vírus do mosaico amarelo da abobrinha de moita no Brasil: caracterização parcial de um isolado encontrado em São Paulo. Fitopatologia Brasileira, v.20, n.1, p.72-79, 1995.

VEGA, J.; REZENDE, J.A.M.; YUKI, V.A.; NAGAI, H. Constatação do vírus do mosaico amarelo da abobrinha de moita ("zucchini yellow mosaic virus") no Brasil, através de MEIAD e ELISA. Fitopatologia Brasileira, v.17, p.118, 1992. /resumo/

WALKEY, D.G.A.; LECOQ, H.; COLLIER, R.; DOBSON, S. Studies on the control of zucchini yellow mosaic virus in courgettes by mild strain protection. Plant Pathology, v.41, p.762-771, 1992.

WANG, H.L.; GONSALVES, D.; PROVVIDENTI, R.; LECOQ, H.L. Effectiveness of cross protection by a mild strain of zucchini yellow mosaic virus in cucumber, melon and squash. Plant Disease, v.75, n.2, p.203-207, 1991.

WYMAN, J.A.; TOSCANO, N.C.; KIDO, K.; JOHNSON, H.; MAYBERRY, K. Effects of mulching on the spread of aphid-transmitted watermelon mosaic virus to summer squash. Journal of Economic Entomology, v.72, n.1, p.139-143, 1979.

YARDEN, G.; HEMO, R.; LIVNE, H.; MAOZ, E.; LEV, E.; LECOQ, H.; RACCAH, B. Cross protection of cucurbitaceae from zucchini yellow mosaic potyvirus. In: EUCARPIA MEETING ON CUCURBIT GENETICS AND BREEDING, 7; Israel, 2000. Proceedings. Belgium: ISHS, 2000. p.349-356.

YEH, S.D.; GONSALVES, D. Practices and perspective of control of papaya ringspot virus by cross protection. Advances in Disease Vector Research, v.10, p.237-257, 1994. 
YEH, S.-D.; GONSALVES, D.; WANG, H.-L.; NAMBA, R.; CHIU, R.-J. Control of papaya ringspot virus by cross protection. Plant Disease, v.72, n.5, p.375-380, 1988.

YUKI, V.A. Epidemiologia e controle do mosaico (VMM-Me) em abobrinha-demoita. Piracicaba, 1990. 84 p. Tese (Doutorado) - Escola Superior de Agricultura "Luiz de Queiroz", Universidade de São Paulo.

YUKI, V.A., COSTA, A.S.; NAGAI, V. Avaliação de perdas induzidas pelo mosaico da abobrinha de moita, causado pelo vírus do mosaico do mamoeiro -estirpe melancia (VMM- Me). Summa Phytopathologica, v.17, n.1, p.40, 1991. /resumo/

YUKI, V.A.; REZENDE, J.A.M.; KITAJIMA, E. W.; BARROSO, P.A.V.; KUNIYUKI, H.; GROPPO, G.A.; PAVAN, M.A. Occurrence, distribution and relative incidence of viruses infecting cucurbits in the State of São Paulo, Brazil. Plant Disease, v.84, n.5, p.516-520, 2000.

ZITTER, T.M.; HOPKINS, D.L.; THOMAS, C.E. Compendium of Cucurbit Diseases. St. Paul: The American Phytopathological Society, 1996. 87p. 